NBER WORKING PAPER SERIES

\title{
TAXATION AND THE EVOLUTION OF AGGREGATE CORPORATE OWNERSHIP CONCENTRATION
}

\author{
Mihir A. Desai \\ Dhammika Dharmapala \\ Winnie Fung \\ Working Paper 11469 \\ http://www.nber.org/papers/w11469 \\ NATIONAL BUREAU OF ECONOMIC RESEARCH \\ 1050 Massachusetts Avenue \\ Cambridge, MA 02138 \\ June 2005
}

We would like to thank Alan Auerbach, Steve Bond, Bill Gale, Bill Gentry, Jim Hines, Emmanuel Saez, Richard Sansing, Gautam Tripathi, our discussants (Jeff Brown and Jeff Strand) and participants at the OTPR/Burch Center conference on "Taxing Corporate Income in the $21{ }^{\text {st }}$ Century" for valuable comments and suggestions on an earlier draft of this paper. Desai acknowledges the financial support of the Division of Research of Harvard Business School. The views expressed herein are those of the author(s) and do not necessarily reflect the views of the National Bureau of Economic Research.

(C2005 by Mihir A. Desai, Dhammika Dharmapala, and Winnie Fung. All rights reserved. Short sections of text, not to exceed two paragraphs, may be quoted without explicit permission provided that full credit, including (C) notice, is given to the source. 
Taxation and the Evolution of Aggregate Corporate Ownership Concentration Mihir A. Desai, Dhammika Dharmapala, and Winnie Fung

NBER Working Paper No. 11469

June 2005

JEL No. G30, H24

\section{ABSTRACT}

Legal rules, politics and behavioral factors have all been emphasized as explanatory factors in analyses of the determinants of the concentration of corporate ownership and stock market participation. An extension of standard tax clientele arguments demonstrates that changes in the progressivity of taxes can also significantly influence patterns of equity ownership. A novel index of the concentration of corporate ownership over the twentieth century in the U.S. provides the opportunity to quantitatively test for the role of taxes in shaping ownership concentration. The index of ownership concentration is characterized by considerable time series variation, with significant diffusion of ownership in the post WWII era and reconcentration in the late 1990s. Analysis of this index indicates that the progressivity of taxation significantly influences corporate ownership concentration and equity market participation as predicted by the model. This evidence supports the intuition of Berle and Means (1932) that taxation can significantly influence patterns of equity ownership .

Mihir A. Desai

Graduate School of Business Administration Harvard University

Soldiers Field

Boston, MA 02163

and NBER

mdesai@hbs.edu

Dhammika Dharmapala University of Connecticut Department of Economics 341 Mansfield Road, Unit 1063

Storrs, CT 06269-1063

dhammika.dharmapala@uconn.edu
Winnie Fung

Kennedy School of Government

Harvard University

79 JFK Street

Cambridge, MA 02138

fung@fas.harvard.edu 


\section{Introduction}

The extent to which corporate ownership is widely dispersed is an important dimension of an economy's corporate governance environment. The mechanisms by which diffuse owners police managers and the reasons why much of the world does not feature diffuse corporate ownership are major themes in the corporate governance literature. The comparative strand of this literature emphasizes legal origins as a critical determinant of the investor rights that facilitate ownership diffusion (e.g. La Porta, Lopez-de-Silanes, Shleifer and Vishny, 1998). However, subsequent efforts to trace the time-series patterns of governance and ownership concentration (e.g. Rajan and Zingales, 2003; Franks, Mayer and Rossi, 2003) have questioned the singular role of legal investor protections, given the diffusion of ownership in the absence of legal protections at various times in the twentieth century. ${ }^{1}$ The dispersion of corporate ownership across households is also closely related to questions surrounding stock market participation that have attracted considerable interest in the recent literature (e.g. VissingJorgensen, 2002; Griffin, Nardari and Stulz, 2004). As a result, the question of what facilitates and propels ownership diffusion remains a central research question in corporate finance and asset pricing.

The role of taxes in retarding or promoting ownership diffusion has largely gone unexplored. This oversight is particularly surprising, as the seminal contribution that identified the issue of the separation of ownership and control (Berle and Means, 1932) was motivated by the observation that high tax rates during World War I marked a major turning point in this separation in the U.S. Specifically, Warshow (1924) and Means (1930) analyze how these highly progressive taxes were associated with a sharp increase in the diffusion of ownership. This paper extends that line of reasoning to analyze how personal taxes have shaped the level of ownership concentration over the rest of the twentieth century.

The precise mechanism by which individual income taxation might facilitate ownership diffusion, as suggested originally in Means (1930), is illustrated with a simple extension to the Miller (1977) model of financial equilibrium. In Miller's model, firms endogenously issue both equity and bonds, with the corporate tax preference for debt financing being offset by a personal

\footnotetext{
${ }^{1}$ Roe (2002) also notes that ownership is not diffuse in countries (such as Sweden and Finland) where corporate law and investor protections appear to be strong. He attributes this to the possibility that political forces would demand anti-shareholder actions in the absence of large blockholders.
} 
tax preference for equity among some investors. In equilibrium, each firm is indifferent about its debt-equity ratio and investors sort into tax clienteles for stock and bonds. An extension of this model shows that an increase in the progressivity of the tax schedule leads to an increase in the fraction of investors holding equity, and thus to a decrease in the concentration of stock ownership across investors. In essence, increased progressivity leads to a greater relative tax penalty on corporate bonds. Firms respond with increased equity issuance, and the identity of the marginal investor shifts to a lower income level, thereby generating a greater diffusion of equity ownership.

To analyze this hypothesis empirically, this paper develops an index of corporate ownership concentration at the economy-wide level, following the methodology used to track income distribution pioneered by Kuznets (1953) and revived by Piketty and Saez (2003). Tax return data is used to construct a Herfindahl index that summarizes the degree of concentration of stock ownership across households over the twentieth century. This index is characterized by significant time-series variation that undercuts the static view of the American example as one where ownership has long been diffuse due to legal protections or political factors. It differs from measures used in existing studies of corporate governance (which typically track the ownership concentration of some sample of large public corporations across countries or through time) and is especially suited to time-series analysis within countries and for understanding the determinants of stock market participation across income groups. The advantages and disadvantages of such an economy-wide measure relative to the firm-specific approach typically employed are discussed in more detail below.

Time-series analysis of the determinants of this index reveals that increases in the progressivity of individual income tax rates are associated with statistically significant and economically meaningful increases in the diffusion of corporate ownership. Controlling for a variety of factors, a one standard deviation change in the top statutory rate is associated with close to a one standard deviation shift in the Herfindahl index. Analysis of the patterns of corporate equity ownership by each quintile of the income distribution confirms the impact of tax rates. This analysis can also be viewed as providing a new perspective on the determinants of equity market participation, suggesting that the progressivity of the tax code may be a contributing factor in stock market participation at lower income levels. This time series analysis finds only weak evidence for the role of valuation levels on equity market participation. 
The analysis finds support for the simple intuition that taxation can impact shareholding patterns and, consequently, levels of ownership concentration and stock market participation. Specifically, highly progressive rates shift the incentives for equity issuance and the distribution of ownership shifts across the income distribution in response. The empirical analysis is robust to controls for a variety of factors including changes in economic conditions, income distribution, stock valuation, the fraction of households filing tax returns, and other tax rates. Analysis of various subperiods confirms that these findings do not reflect changing patterns in reporting or the increase in equity ownership through tax-advantaged accounts. While suggesting that taxes are an underappreciated determinant of the level of corporate ownership diffusion, the paper does not claim that taxation alone can explain variations across time and countries in the level of ownership diffusion. The concluding section of the paper locates these results within the broader literatures on the determinants of corporate governance and on the rationales for tax progressivity, and suggests possible avenues for further research.

The rest of the paper proceeds as follows. Section 2 discusses the links to the relevant literatures. Section 3 develops a simple model of financial equilibrium and derives implications for the effects of taxation on ownership concentration. Section 4 develops the measures of ownership concentration and explains its relative merits and drawbacks. Section 5 presents the results and Section 6 concludes with avenues for future research.

\section{2. $\quad$ Related Literature}

This paper contributes to, and draws on, several distinct literatures. This section begins by reviewing historical and qualitative assessments of the interactions between the evolution of

shareholding patterns and the income tax. Next, the more recent literature on the determinants of corporate governance is reviewed, with a particular emphasis on political interpretations of corporate governance institutions. Finally, the emerging literatures on the links between taxation and governance and the reasons for limited equity market participation are also briefly reviewed.

\subsection{The Evolution of the U.S. Income Tax and of Stock Ownership Diffusion}

Historical, political and early economic analysis of the evolution of the income tax place much emphasis on the role of the income tax in determining corporate ownership patterns. Means (1930), building on the work of Warshaw (1924), provides the classic statement of this argument. Without modern statistical techniques, Means argues that the dramatic rise in 
the diffusion of stock ownership from 1916 to 1921 was attributable to sharply progressive tax changes. Specifically, following Warshaw, Means employs shareholder records for large, public firms and data compiled from tax records to show that stock ownership diffused sharply during this period, that other non-tax explanations for this diffusion are insufficient, and that wealthy individuals shifted toward tax-advantaged assets including tax-exempt bonds, real estate and life insurance. Means (p. 589) argues that in effect these tax changes made "the rich man not only a poor market for stocks but an actual seller of stock and the man of moderate income an excellent buyer."

Berle and Means (1932) go on to note in their work that "the rise in popularity of [customer and employee ownership] was undoubtedly due in a considerable measure to the influence of Federal taxation. Both developed most vigorously during a period in which the weight of the Federal surtaxes was such as to make the individual with a large income an extremely poor market for corporate securities. The difficulty of obtaining new capital from the usual sources was thus increased and a new market for corporate securities was sought in the man of smaller income...” (p. 59). Such an analysis is an early statement of the tax clientele argument that is extended in this paper. Means (1930, p. 592) concludes that the World War I taxes "accelerated that separation of ownership and control which has become a marked feature of our economy."

In addition to the portfolio effects emphasized by economists studying the separation of ownership and control, many early economic analyses of the income tax attributed the introduction and spread of income taxation in the U.S. and abroad in part to a desire to redistribute wealth and income. ${ }^{2}$ Historical and political investigations of the evolution of the income tax mirror this emphasis on redistributional motives. ${ }^{3}$ Taken together, these various qualitative assessments of the motivations and effects of income taxes indicate a plausible role for income taxation in shaping ownership patterns of corporate stock.

\subsection{Determinants of Corporate Governance Arrangements}

As discussed above, the arrangements that govern the relationship between shareholders and managers have drawn increased attention. Morck and Steier (2005) provide a useful

\footnotetext{
${ }^{2}$ See Seligman (1911), and Musgrave's (1992) critique of Schumpeter's views on the evolution of the income tax.

${ }^{3}$ Ratner (1942) and Brownlee (1996) provide detailed discussions of the political motivations for various changes in the tax code.
} 
overview of the factors that account for noted cross-country differences - ideology, legal rules, the role of trust in societies - as well as an overview of various country studies. While taxation is seldom discussed in these studies, a few exceptions stand out. Morck, Percy, Tian and Yeung (2004) study the evolution of ownership concentration in Canada and emphasize the role of estate taxes in determining when families choose to disgorge large shareholdings. Morck (2004) highlights the role of the double taxation of intercorporate dividends in the United States in discouraging the formation of business groups through pyramidal ownership structures.

Of course, tax policy reflects political impulses; Roe (1994) argues that the particularly diffuse nature of ownership in the U.S. was the result of political forces that prevented the persistence of large shareholders. Specifically, Roe emphasizes antitrust rules and financial regulation - particularly of banks and mutual funds - as being critical to shaping the diffusion of ownership concentration. The potential role of taxes in shaping redistributions of corporate ownership is related to Roe's emphasis on politics in shaping corporate governance outcomes. It should be noted, however, that several dramatic tax changes in the U.S. - including the one emphasized by Berle and Means (1932) - were related to wartime efforts rather than conscious politically-motivated changes in the tax code.

\subsection{Taxation and Corporate Governance}

Studies of taxation and corporate governance have been converging in an emerging literature. Desai, Dyck and Zingales (2004) note that the corporate tax makes the state the largest minority shareholder in most corporations. As a consequence, the workings of the corporate tax may well influence, and be influenced by, the relationship between managers and outside shareholders. Strong complementarities may exist between tax avoidance and managerial diversion because concealing income from the tax authorities through complex transactions reduces the ability of shareholders to monitor manager behavior, thereby making diversion less costly for managers. Such relationships appear to be operative based on evidence from Russia and cross-country differences in the way in which corporate tax revenues respond to corporate tax rate changes. Desai and Dharmapala $(2005 a, b)$ investigate the relevance of these ideas in the U.S. setting by developing a conceptual framework for understanding how changes in incentive compensation can change corporate tax avoidance activity, and how such activity is valued by financial markets. Firm-level governance measures are found to be an important 
determinant of the role of high-powered incentives in changing sheltering decisions and of how markets value avoidance.

In addition to this work on the role of corporate taxation in influencing corporate governance outcomes, dividend taxation has also been shown to interact with governance arrangements. For example, Chetty and Saez (2004) and Brown, Liang and Weisbenner (2004) both note that managerial compensation patterns were an important determinant of firm responses to the 2003 dividend tax cut. ${ }^{4}$ Similarly, Perez-Gonzalez (2003) finds that payout policy is significantly influenced by the presence of large individual shareholders. Each of these papers indicates that tax incentives interact with ownership and governance institutions in important ways.

\subsection{Stock market participation and portfolio allocations}

Heterogeneity in stock market participation rates across the income distribution has generated considerable interest among theorists and empirical researchers. For example, Haliassos and Bertaut (1995) and Vissing-Jorgensen (2002) argue that transaction costs, either in the form of explicit trading costs or informal psychic costs of information acquisition, can explain why many households do not participate in equity markets. ${ }^{5}$ In one effort to explain these patterns, Poterba (2001) develops an after-tax capital asset pricing model and argues that tax rules are a potentially important determinant of household portfolio structure. Of particular note are the effects of tax incentives in influencing the location of assets across taxable and nontaxable accounts, as in Shoven and Sialm (2004) and Dammon, Spatt and Zhang (2004). Their logic on the preferred habitat for assets is extended across the income distribution by the analysis in this paper. In essence, the nature of tax progressivity, and changes to it, may constitute an underappreciated reason for heterogeneity in portfolio allocations across income classes and across time.

\section{Hypothesis Development}

\footnotetext{
${ }^{4}$ Chetty and Saez (2004) show that increases in dividend payments in response to the tax cut were most pronounced among firms with high levels of managerial ownership, as well as those with high levels of institutional ownership. Managers with large stock option holding, however, were less likely to respond to the tax change (Brown, Liang and Weisbenner (2004)).

${ }^{5}$ Curcuru, Heaton, Lucas and Moore (2004) review this and related literatures.
} 
The basic hypothesis developed in this section is that increases in the progressivity of the personal income tax system lead to a greater diffusion of stock ownership across the income distribution. This idea is illustrated using a simple extension to the model of financial equilibrium introduced in Miller (1977) (see also Auerbach (2002, pp. 1271-1273)). In Miller's model, firms endogenously issue both equity and bonds. The corporate tax system creates a preference for debt financing, as interest payments are tax-deductible to the corporation while payouts to equityholders are not. Miller (1977) argues that this is offset, for some investors, by a personal tax preference for equity returns because of the lower personal tax rate on capital gains. This insight leads to the characterization of an equilibrium in which each firm is indifferent about its debt-equity ratio, and in which investors sort into clienteles for stocks and bonds on the basis of their tax characteristics. In this section, Miller's model is extended to consider the consequences of an increase in the progressivity of the tax schedule for shareholding patterns.

Assume that firms face an exogenously fixed corporate tax rate $\tau €(0,1)$, and can issue two kinds of assets - bonds and stock. Firms pay interest on the bonds they issue, and pay out a fraction $d \mathrm{e}(0,1)$ of the returns to equityholders as dividends (with the remaining fraction $(1-d)$ being received by stockholders in the form of capital gains). The dividend yield $d$ is assumed to be fixed, and identical for all firms. There is no uncertainty about the returns from either bonds or equity. A continuum of investors exists, distinguished by income $y \in\left[0, y^{\max }\right] \subset \mathfrak{R}_{+}$. The distribution of investors over the interval $\left[0, y^{\max }\right]$ is represented by the pdf $f(y)$ and the corresponding $\operatorname{cdf} F(y)$. The only restriction placed on this distribution is that the $\operatorname{cdf} F(y)$ is strictly monotonically increasing (i.e. $f(y)>0$ ) over $\left[0, y^{\max }\right]$. Investors are restricted to holding nonnegative amounts of the two kinds of assets - corporate bonds and equity - issued by firms. ${ }^{6}$

Investors are assumed to face a zero tax rate on capital gains; a positive tax rate on capital gains would reduce the extent of the personal tax preference for equity, but (as long as capital

\footnotetext{
${ }^{6}$ Tax-exempt assets (such as municipal bonds) could be introduced into the model without fundamentally affecting the results. The restriction on short sales is standard in the tax clientele literature, in order to rule out cases where investors can eliminate all taxes through arbitrage among assets with different tax characteristics. This also implicitly rules out the "tax irrelevance" view that taxpayers are able to use financial engineering to eliminate taxes on returns from equity. While doing so may be theoretically feasible, the empirical evidence suggests that taxes are important. Even in the context of capital gains taxation (where opportunities for avoidance are particularly abundant because of the realization doctrine), Auerbach, Burman and Siegel (2000) find that most realized capital gains are not sheltered by losses. Even in their sample of high-income taxpayers (some of whom are "sophisticated" in the sense that they trade in derivatives) "average effective tax rates on realized capital gains are very close to statutory rates" (p. 378).
} 
gains are tax-favored relative to dividends and interest) would not affect the basic conclusions. An investor's tax liability on dividend and interest income is a function of her total pretax income $y$, and is determined by the tax schedule $t(y)$. This is assumed to be continuous and twice-differentiable over the interval $\left(0, y^{\max }\right]$, and to be strictly increasing and convex $\left(t^{\prime}(y)>0\right.$ and $\left.t^{\prime \prime}(y)>0\right)$ over $\left(0, y^{\max }\right]$, with $t(0)=t^{\prime}(0)=0$. As the marginal tax rate $t^{\prime}(y)$ faced by an individual with income $y$ is strictly increasing in income, $t(y)$ satisfies a stronger notion of progressivity (sometimes termed "marginal rate progressivity") than the standard definition (which requires only that the average tax rate increases with income). This appears appropriate in this context, as investors' portfolio decisions are based on their marginal tax rates. In addition, further restrictions on $t(y)$ are imposed to ensure that the marginal tax rate is everywhere strictly less than $100 \%$ (i.e. $t^{\prime}\left(y^{\max }\right)<1$ ), and that it is sufficiently large to ensure the existence of an equilibrium in which investors hold both types of assets (i.e. $\left.t^{\prime}\left(y^{\max }\right)>\frac{\tau}{1-d(1-\tau)}\right)$.

In Miller's (1977) equilibrium, the relative pretax returns on bonds and stock adjust so that the return to equity demanded by investors equals the after-tax interest rate (see also Auerbach, 2002, p. 1271). Given this, a dollar of interest income yields an after-tax amount of $\$\left(1-t^{\prime}(y)\right)$ to an investor with income $y$ (noting that the interest is deductible to the firm), while a dollar of equity returns leads to $\$ d$ of dividends, and so yields an after-tax amount of $\$(1-\tau)(1-$ $\left.d t^{\prime}(y)\right)$ (noting that the firm pays the corporate tax on the income paid out to the investor). Given the assumptions regarding $t(y)$ made above, an investor with income $y=0$ strictly prefers interest income to equity returns (as $1>1-\tau$ ), while an investor with income $y=y^{\text {max }}$ strictly prefers equity to bonds $\left(\right.$ as $\left.(1-\tau)\left(1-d t^{\prime}\left(y^{\max }\right)\right)>1-t^{\prime}\left(y^{\max }\right)\right)$. By the continuity of $t^{\prime}(y)$, there exists a marginal investor with income $y^{*}$ who is indifferent between holding bonds and equity; $y^{*}$ is defined by the expression:

$$
1-t^{\prime}\left(y^{*}\right)=(1-\tau)\left(1-d t^{\prime}\left(y^{*}\right)\right)
$$

All other investors strictly prefer either bonds or stock. The degree of preference can be characterized by the ratio of the after-personal-tax value of $\$ 1$ of interest income to the afterpersonal-tax value of $\$ 1$ of equity income, denoted by $\theta(y)$ :

$$
\theta(y) \equiv \frac{1-t^{\prime}(y)}{1-d t^{\prime}(y)}
$$


As $d<1, \theta(y)<1$ for all $y>0$. The smaller is $\theta$, the greater is the investor's tax preference for equity. It follows straightforwardly from Eq. (2) that $\theta^{\prime}(y)<0$, so that the personal tax preference for equity increases with income.

The corporate tax preference can be analogously represented by $(1-\tau)$; the higher the corporate tax rate, the greater the corporate tax preference for debt. The expressions $(1-\tau)$ and $\theta(y)$ are depicted graphically in Figure 1. As shown there, they characterize a financial equilibrium with the following features (Miller, 1977; Auerbach, 2002). All investors with incomes $y<y^{*}$ hold only debt, as the marginal personal tax rates they face are sufficiently low that the personal tax preference for equity is outweighed by the corporate tax preference for debt. In contrast, all investors with incomes $y>y^{*}$ face marginal personal tax rates that are sufficiently high that the personal tax preference for equity outweighs the corporate tax preference for debt, and so hold only equity. Firms issue a sufficient quantity of bonds to satisfy the demand of investors with incomes $y<y^{*}$, and a sufficient amount of equity to satisfy the demand of investors with incomes $y>y^{*}$. The fraction of investors holding equity is $\left(1-F\left(y^{*}\right)\right)$. The aggregate debt-equity ratio for the corporate sector is determined by investors' demands for the two types of assets, but each firm is indifferent about its capital structure.

The primary question of interest here is how this equilibrium changes in response to an increase in the progressivity of the tax schedule $t(y)$. Suppose that the original tax schedule $t(y)$ is replaced by: ${ }^{7}$

$$
t^{+}(y)= \begin{cases}t(y) & \text { if } y<y_{0}<y^{*} \\ \alpha t(y) & \text { if } y \geq y_{0}\end{cases}
$$

where $y_{0}$ is some arbitrary level of income chosen so that it is lower than the income of the marginal investor $y^{*}$, and where $\alpha>1$ (satisfying the constraint that the marginal tax rate is everywhere below $100 \%$ requires that $\alpha$ is also sufficiently close to $\left.1: \alpha<\frac{1}{t\left(y^{\max }\right)}\right)$. The new tax schedule involves an increase in progressivity in a very general sense. The marginal tax rate faced by higher-income investors increases (as $\alpha t^{\prime}(y)>t^{\prime}(y)$ ), while the marginal rate for lowerincome investors stays constant. There is also an increase in the convexity of the tax function for

\footnotetext{
${ }^{7}$ In the theoretical literature, the relative progressivity of different tax schedules is typically analyzed using the concept of Lorenz dominance (e.g. Kakwani, 1977); however, a simple example comparing two different tax schedules suffices to illustrate the basic point being made here.
} 
higher-income investors (as $\alpha t^{\prime \prime}(y)>t^{\prime \prime}(y)$ ), so that (over the range $\left[y_{0}, y^{\max }\right]$ ) there is an increase in the rate at which the marginal tax rate increases with income.

Investors with incomes below $y_{0}$ are unaffected by the new tax schedule. The personal tax preference parameter (analogous to Eq. (2)) over $\left[y_{0}, y^{\max }\right]$ is now:

$$
\theta^{+}(y) \equiv \frac{1-\alpha t^{\prime}(y)}{1-d \alpha t^{\prime}(y)}
$$

For small changes in $\alpha, \theta^{+}$is decreasing in $\alpha$. Thus, it follows that $\theta^{+}\left(y_{0}\right)<\theta\left(y_{0}\right)$ (as shown in Figure 1), and that the original marginal investor now strictly prefers equity (i.e. $\theta^{+}\left(y^{*}\right)<\theta\left(y^{*}\right)=$ $1-\tau)$. It can also be shown that $\frac{\partial^{2} \theta^{+}(y)}{\partial y \partial \alpha}<0$, so that over the range $\left[y_{0}, y^{\max }\right]$ and for $\alpha$ sufficiently close to $1, \theta^{+\prime}(y)<\theta^{\prime}(y)$. Thus, the new tax preference parameter in Eq. (4) has a more negative slope (i.e. falls more rapidly with income) than does $\theta$, as illustrated in Figure 1. In essence, all investors with incomes above $y_{0}$ now have a stronger personal tax preference for equity, and this preference now increases more rapidly with income. The increased progressivity of the tax schedule thus entails a greater relative personal tax disadvantage for bonds.

The corporate tax preference $(1-\tau)$ and the new personal tax preference $\theta^{+}(y)$ characterize a new financial equilibrium. If $\theta^{+}\left(y_{0}\right)>1-\tau$, then (as shown in Figure 1) because $\theta^{+}\left(y^{*}\right)<(1-\tau)$ and $\theta^{+}(y)$ is continuous over the interval $\left(y_{0}, y^{*}\right]$, there exists a new marginal investor with income $y^{* *} \in\left(y_{0}, y^{*}\right)$, defined by the expression:

$$
1-t^{+}\left(y^{* *}\right)=(1-\tau)\left(1-d t^{+\prime}\left(y^{* *}\right)\right)
$$

(i.e. $\theta^{+}\left(y^{* *}\right)=1-\tau$, with $\left.y^{* *}<y^{*}\right)$. In equilibrium, all investors with income $y>y^{* *}$ hold equity, and all investors with income $y<y^{* *}$ hold bonds.

Recalling that the distribution of investors $F(y)$ is strictly monotonically increasing, the fraction of investors holding equity rises from $\left(1-F\left(y^{*}\right)\right)$ (in the old equilibrium) to $\left(1-F\left(y^{* *}\right)\right)$ (in the new equilibrium). Thus, the increased progressivity of the tax schedule leads to an increased diffusion of stock ownership, as some lower-income investors (those between $y^{* *}$ and $\left.y^{*}\right)$ switch from bonds to equity. The aggregate debt-equity ratio falls as firms issue more equity to satisfy the new demand from investors with incomes between $y^{* *}$ and $y^{*}$ who enter the market for corporate stock. 
If $\theta^{+}\left(y_{0}\right) \leq 1-\tau$, the continuity argument above does not apply, but the basic conclusion is unchanged: ${ }^{8}$ the fraction of investors holding equity increases following an increase in the progressivity of the tax structure. Of course, this model is highly simplified. For example, it does not incorporate any uncertainty about asset returns (Auerbach and King, 1983), nor does it allow firms to respond to tax changes by adjusting their dividend yield. Nonetheless, it illustrates very simply a basic intuition regarding tax progressivity and financial equilibrium that is likely to be quite robust across a variety of settings in which investors form tax clienteles for different types of assets. ${ }^{9}$

\section{The Index of Aggregate Ownership Concentration}

\subsection{Data Source}

Individual income tax return data are compiled annually by the Statistics of Income Division (SOI) of the Internal Revenue Service (IRS). They are available in two forms: detailed statistical tables showing aggregated data by income brackets (for years 1916 to 2004) ${ }^{10}$ and micro-files showing disaggregated data by individuals (for years 1960 to 1999). ${ }^{11}$ The IRS processes more than 100 million tax returns each year, and the SOI uses about 200,000 returns to compute its statistics. The 1916-2004 statistical tables include information on the number of tax returns, the total amounts of income reported, and the income composition for a large number of income brackets. More than forty income brackets are used, with income defined as adjusted gross income less deficit (AGI). For each income bracket, the different sources of income are

\footnotetext{
${ }^{8}$ Suppose that $\theta^{+}\left(y_{0}\right)=1-\tau$; then, the marginal investor has income $y_{0}$, so that $y^{* *}=y_{0}<y^{*}$. In equilibrium, all investors with income $y>y_{0}$ will hold equity, and all investors with income $y<y_{0}$ will hold bonds, and the fraction of investors holding equity rises from $\left(1-F\left(y^{*}\right)\right)$ to $\left(1-F\left(y_{0}\right)\right)$. If $\theta^{+}\left(y_{0}\right)<1-\tau$, there is no investor who is indifferent between debt and equity (i.e. a marginal investor does not exist, as $t^{+}(y)$ has a discontinuity at $y=y_{0}$ ). However, all investors with income $y \geq y_{0}$ strictly prefer equity, and all investors with income $y<y_{0}$ strictly prefer bonds. As investors with income of precisely $y^{* *}$ constitute a set of measure zero, the equilibrium does not differ in any significant way from that when $\theta^{+}\left(y_{0}\right)=1-\tau$; the fraction of investors holding equity rises from $\left(1-F\left(y^{*}\right)\right)$ to $\left(1-F\left(y_{0}\right)\right)$.

${ }^{9}$ The previous version of this paper emphasized an alternative mechanism by which increased progressivity could lead to increased diffusion. Specifically, the supply of securities was held fixed, and increased progressivity led to wealth effects that generated similar results. In contrast, the model here emphasizes supply responses as the mechanism for the diffusion.

${ }^{10}$ In 1913, a constitutional amendment allowed the U.S. government to raise revenue by introducing an individual income tax. Later, the Revenue Act of 1916 mandated the annual publication of statistics related to internal revenue laws.

${ }^{11}$ These micro-files are made publicly available after identifiable taxpayer information has been deleted to ensure confidentiality. These 1960-1998 micro-files allow us to check that the method of interpolating data from the pre1960 statistical tables produces accurate results. Note that there are three years during the 1960-1999 period (1961, 1963, and 1965) for which micro-files are not available, so aggregated data in the statistical tables are used instead.
} 
broken down and reported separately. In particular, the amount of dividend income is reported for each income bracket. ${ }^{12}$ Dividend income is used to proxy for stock ownership, and the share of dividends accruing to each income group is used to measure the distribution of stock ownership.

Tax return data are in some respects more reliable and accurate than most other field survey data, since there are penalties for misreporting tax returns (although there are also incentives for under-reporting, unlike in most field surveys). They also have the advantage of being available for many years, starting as early as 1916, enabling the analysis of the evolution of ownership concentration over the past 80 years or more. Although tax laws have changed over the years, it is quite feasible to track the changes and make necessary adjustments to preserve year-to-year consistency. Moreover, tax return data cover almost the entire population, and in particular, all middle and high income individuals. The data also over-sample high income individuals, thus enabling the breakdown of the top income group into finer fractiles, which is important because the top income group is very heterogeneous in terms of its income composition, with capital income being a major source of difference (Piketty and Saez, 2003).

\subsection{Empirical Measures of Ownership Concentration Using Individual Tax Returns}

The shares of total stocks owned by different income groups are first estimated and then used to construct a Herfindahl index of ownership concentration. As there is no data on the actual amount of stocks owned by individuals, dividend income reported in individual tax returns is used as a proxy for stock ownership. This is similar to the empirical strategy used by Means (1930) in his study of the diffusion of stock ownership in the 1920s.

The use of dividend shares as a proxy for stock ownership raises a number of issues. First, dividend income will be an exact proxy for stock ownership only if all stocks pay out dividends at the same rate. In practice, not all stocks pay out dividends, and not all stocks that pay out dividends pay at the same rate. However, this study is only concerned with changes in the proportions of total dividends received by different income groups. If one assumes that the propensity of different income groups to invest in stocks with different dividend policies remains relatively constant over time, then changes in dividend shares can be regarded as a reasonable

\footnotetext{
${ }^{12}$ Dividends are defined by the IRS as "distributions of money, stock, or other property received by taxpayers from domestic and foreign corporations, either directly or passed through estates, trusts, partnerships, or regulated investment companies."
} 
proxy for changes in the distribution of stock ownership. It is possible that if firms lower their dividend payments in response to higher taxes, this methodology may misattribute the decline in dividend income to a fall in stock ownership. The empirical analysis described below controls for changes in the average dividend yield and it is well-known that firms are extremely reluctant to change their dividend policies (see Lintner (1956) and Brav et al., (2005)).

Second, recent studies documenting a decreasing propensity of firms to pay out dividends (Fama and French, 2001) may raise concerns about the use of dividends to measure corporate ownership concentration. However, total dividends, as reported on tax returns, increased by more than threefold from $\$ 34$ billion to $\$ 147$ billion from 1916 to 2000 (in year 2000 dollars). Average dividend income (total dividends received divided by total number of tax units) lay mostly within the range of $\$ 600-\$ 800$ for the first half of the century, and then increased to $\$ 800-\$ 1,000$ for the second half (in 2000 dollars), suggesting that dividends may provide a reasonable way to proxy for corporate ownership over the century. An alternative series based on estate tax returns is also investigated to confirm the reliability of the dividend-based measure of ownership concentration. ${ }^{13}$

Finally, dividends received through pension plans and retirement saving accounts are not reported as dividends on individual income tax returns. The amount of total dividends reported on individual tax returns has always been less than the amount of dividends paid out by corporations, as reported in National Income and Product Accounts (NIPA), and the gap between the two has widened. ${ }^{14}$ Part of the gap may be explained by dividends paid out to foreigners who are not required to file income tax returns, but the declining ratio in the 1980s and 1990s is due mostly to the growth of funded pension plans and retirement saving accounts through which individuals receive dividends that are never reported on income tax returns. For rich investors, this additional source of dividends is likely to be very small relative to dividends directly reported on their tax returns (i.e. dividends from directly owned stocks or dividends received

\footnotetext{
${ }^{13}$ A related issue is that this measure relies on reported dividends received. As such, any observed changes in ownership shares may merely reflect changes in the reporting of income. A failure to report dividends will have no effect on this study if all income groups misreport by approximately the same proportion and this pattern is relatively steady through time. The relevance of underreporting is investigated below by controlling for the share of filers.

${ }^{14}$ The ratio of total dividends reported on tax returns to personal dividends paid out by corporations as reported in the NIPA has declined continuously over the period 1929 to 2000, starting from a level close to $90 \%$ in 1929 , declining slowly to $60 \%$ in 1988 , and dropping much more rapidly to less than $40 \%$ in 2000 .
} 
through mutual funds). If the dividends received through pension plans and retirement saving accounts are included in the estimates of dividend shares, then one should expect the middle income group to experience a greater proportionate increase in dividend income, and therefore a greater observed shift in stock ownership from the rich to the less-well-off. Investigating subperiods where these effects are likely to be less relevant permits consideration of the influence of tax-deferred accounts on the findings in this paper.

The total population is first divided into five income fractiles in such a manner that they can be consistently compared over time. ${ }^{15}$ Following the notation used by Piketty and Saez (2003), the income fractiles are denoted by P0-P20 (the bottom 20\% income group, i.e. the poorest $20 \%$ of the population), P20-P40 (the next 20\%), P40-P60, P60-P80, and P80-P100 (the top $20 \%$, i.e. the richest $20 \%$ of the population). ${ }^{16}$ Top income fractiles are further divided into P90-P100 (top 10\%), P99-P100 (top 1\%), P99.9-P100 (top 0.1\%), and P99.99-P100 (top $0.01 \%) .{ }^{17}$ The share of dividend income is then calculated for the different income fractiles by dividing the amount of dividend income accruing to different income fractiles by the total amount of dividends reported. This is referred to as the "dividend share," and the time series as the "dividend series." Table 1 shows the dividend share for the different income fractiles from 1916 to 2000 .

Next, the dividend shares of the five income fractiles are used to construct a Herfindahl index of concentration. ${ }^{18}$ The concentration index for year $t$, denoted by $C_{t}$, is defined as:

$$
C_{t}=\sum_{i=1}^{5} s_{i t}^{2}
$$

\footnotetext{
15 The term "income fractiles" is used in a sense distinct from the "income brackets" used by the IRS, which are problematic in two ways. First, the income bracket of, say, $\$ 3,000-\$ 4,000$ in 1916 is very different from the $\$ 3,000$ $\$ 4,000$ income bracket in 2000. Even if one adjusts for inflation, there is still a second problem: the income brackets do not contain the same proportion of total population. In that case, a change in dividend income reported by a particular income bracket may simply reflect a change in the number of individuals in that bracket and not a change in dividend share. A better way to define income groups is to divide the total population into groups with the same proportion of total population; these groups are referred to here as "income fractiles."

${ }^{16}$ Of course, the income thresholds for the different income fractiles vary over time. For example, in 2000, the bottom $20 \%$ income group earns less than $\$ 17,000$ a year. The top $20 \%$ income group has an income of more than $\$ 70,000$, while the top $10 \%$ has an income of more than $\$ 90,000$.

${ }^{17}$ Since the top income group holds a majority of total stocks in the economy (the top $10 \%$ holds almost $70 \%$ of total stocks), considering only $0.01 \%$ of the total population still yields a significant share of stock ownership (for example, in 2000 , the top $0.01 \%$ holds $9 \%$ of total stocks, which is greater than the share of stocks held by the bottom $40 \%$ income group).

${ }^{18}$ Using decile rather than quintile dividend shares (i.e. dividing the total population into ten income fractiles) leads to a concentration index that is highly consistent, with the same pattern of changes in ownership concentration.
} 
where $s_{i t}$ is the dividend share of income quintile $i$ in year $t$. The value of $C_{t}$ lies between 0.2 and 1. A value of 0.2 indicates that stock ownership is very dispersed across income groups, while a value of 1 indicates that stock ownership is very concentrated among a particular income group. Column (6) of Table 1 reports the Herfindahl index from 1916 to 2000, and Figure 2 plots the index over this time period. This index provides a summary measure of the change in stock ownership concentration over the past century.

\subsection{The Dynamics of Ownership Concentration}

Figure 2 shows that stock ownership experienced dramatic deconcentration over the past century, going from an index of 0.85 in the late 1910 s to below 0.50 in the $1990 \mathrm{~s}$. This deconcentration did not take place as a one-time phenomenon, nor was it a simple monotonic decline over the century. One can demarcate the twentieth century into five periods with distinct changes in ownership patterns.

First, the WWI and post-WWI period (1916-1927) featured a concentration and then sudden diffusion of stock ownership. Stock ownership started out as very concentrated at the beginning of the century, with an index of 0.75 in 1916. Ownership became even more concentrated during WWI, with the index rising steadily to its peak of 0.85 in 1920 . 1921 saw a precipitous decline of the index to 0.70 , and this sudden great dispersion of stock ownership is consistent with the findings of Means (1930). Second, the period from 1928 to 1944, featured a marked diffusion of stock ownership. After 1921, concentration remained relatively steady at about 0.77 for several years, before dropping to below 0.70 in 1929 . In the aftermath of the Depression, the index fell to 0.62 by 1944 . Third, the post-WWII period featured a concentration of stock ownership with the concentration index jumping from 0.62 to 0.75 in a relatively short period. ${ }^{19}$ Fourth, the 1950 s to early 1990 s constitute an extended period of ownership diffusion. Gradual diffusion began in the 1950s and then accelerated through the 1980s and early 1990s. More precisely, the index declined from 0.75 in 1946 to 0.60 in 1980. The 1980s and early 1990s saw a sharp deconcentration of stock ownership from 0.60 to 0.48 . Finally, the late 1990s featured a marked re-concentration of stock ownership. The index of concentration of corporate ownership increased sharply back to 0.59 in the late $1990 \mathrm{~s}$.

\footnotetext{
${ }^{19}$ It is possible that this may be due to the dramatic increase in the fraction of households filing tax returns during the WWII era. The empirical analysis below controls for this, and also tests the robustness of the results to excluding the period up to 1945 .
} 


\section{4. $\quad$ Alternative Measures Using Estate Tax Returns}

To test how closely the dividend series approximate actual stockholding behavior, it is possible to compare it to an "equity series" constructed using estate tax returns. Estate tax returns data report the actual amount of equity held by the decedent filing estate tax return. However, there is a major caveat to using estate tax returns data. Due to large tax exemption levels, less than $5 \%$ of the overall U.S. decedent population is required to file estate tax returns. ${ }^{20}$ Therefore the construction of equity series using estate tax returns data is confined to the top $1 \%$, top $0.1 \%$, and top $0.01 \%$ income fractiles. This is the reason why individual income tax returns data, which covers the whole population, is chosen instead of estate tax returns data to construct the time series of ownership concentration.

The equity series for these fractiles is constructed using the estate tax returns data compiled by Kopczuk and Saez (2004). ${ }^{21}$ The amount of equity reported by an income fractile is divided by the total amount of equity in the economy (as estimated by Kopczuk and Saez (2004)) in order to calculate the "equity share" for that income fractile. Figure 3 shows that for most of the twentieth century the Herfindahl index of concentration based on dividend shares corresponds closely to the equity series based on estate tax returns. This provides some support for the claim that changes in dividend shares approximate changes in shares of stock ownership; however, there are two main caveats.

First, further comparison of ownership shares for the same fractiles reveals that the dividend series shows smaller fluctuations than the equity series, and the share of stocks implied by the dividend series is systematically smaller than the actual share of stocks owned. This evidence suggests that the very rich may prefer to hold stocks that do not pay out dividends. Such stockholding preference may explain why the dividend series is systematically lower than the equity series. However, if this stockholding preference of wealthy individuals does not change over time, then even though the dividend series will underestimate the shares of total stocks accruing to the high income group, the changes in dividend shares will still reflect changes in the concentration of stock ownership.

\footnotetext{
${ }^{20}$ For example, in 2000 , the estate tax filing threshold was $\$ 675,000$, and only $4.4 \%$ of the overall U.S. decedent population was required to file estate tax returns.

${ }^{21}$ Kopczuk and Saez (2004) use the estate multiplier method first developed by Mallet (1908) to estimate top wealth shares of the living population over the past century. Their wealth composition series is used here to construct shares of corporate stocks held by different income groups.
} 
Second, the index based on dividend shares and the equity series appear to diverge after about 1975. This does not necessarily indicate that the dividend series becomes a worse measure after this time; indeed, it is possible that the problem lies with the estate tax measure. Equity held at death may not accurately reflect equity ownership during one's life, for example, because of the tax incentives to donate appreciated stock late in life. Such issues may have been particularly important when stocks experienced large capital gains in the 1990's. Nonetheless, the empirical analysis in Section 5 below tests for the robustness of the results when the final 25 years of the sample period are omitted. Despite the divergence between the dividend and equity series over that period, the results are highly consistent with those from the entire sample period.

\subsection{Comparisons with Measures Employed in Studies of Corporate Governance}

While Berle and Means (1932) studied ownership diffusion through the use of both tax return data and more granular work on the shareholders of large, public firms, the literature since then has exclusively employed hand-collected data on the shareholders of the largest firms in order to study corporate governance (e.g. La Porta et al. (1998), Franks, Mayer and Rossi (2003), Becht and Delong (2004)). Such an approach has some obvious advantages relative to the use of tax returns. Specifically, such approaches emphasize the experience of large, public firms where external financing is most important, and also allow for identification of complex shareholding arrangements. As such, such efforts may capture the central issue underlying agency theory - the ability and incentives of shareholders to monitor managers - more precisely than can tax return data.

Nonetheless, the relative absence of studies using tax return data is surprising. Even though tax return data cannot provide detailed measures of ownership patterns for individual firms, it can be used to shed light on wider issues of corporate governance, such as the role of investor protections and other factors related to agency costs in shaping widespread stock ownership. In addition, tax return data are particularly well-suited to analyzing the relationship between aggregate patterns of corporate ownership and such factors as tax progressivity. Tax return data allow for analysis of the economy as a whole, a depiction of the levels of participation across separate income classes and can provide a summary measure of concentration across time and countries.

\section{Empirical Specification and Results}




\subsection{The Empirical Specification}

The aim of the empirical analysis is to investigate the effects of changes over time in the progressivity of personal income tax rates on changes in the concentration index described in Section 4 above. The analysis seeks to capture changes in progressivity by estimating the effects of changes in the top statutory personal tax rate, while controlling for changes in personal income tax rates at lower levels of income. Specifically, these controls are the marginal rates applicable at incomes of $\$ 50,000, \$ 100,000, \$ 250,000$ and $\$ 500,000$ (all in 1999 dollars), as computed by Sialm (2003). Including these controls also (at least to some extent) holds the average tax rate constant, thus isolating the portfolio effects analyzed in Section 3 from the wealth effects of tax changes.

There are of course many factors other than personal tax rates that may influence patterns of stock ownership. The distribution of ownership could, for instance, be affected by a growth in stock market participation due to increased financial sophistication among those with lower incomes. The literature on stock market participation has identified a number of determinants of the propensity to own corporate equity. For example, Vissing-Jorgensen (2002) finds that (nonfinancial) income positively affects the likelihood of participation. The effects of income are controlled for here by including changes in real GDP per capita (obtained from the National Income and Product Accounts (NIPA) produced by the Bureau of Economic Analysis). In addition, Griffin, Nardari and Stulz (2004) find that participation tends to increase in response to strong stock market performance. Thus, changes in the price-earnings $(\mathrm{P} / \mathrm{E})$ ratio (obtained from an updated version of the dataset in Shiller (1989)) ${ }^{22}$ are included as an additional control.

A number of other relevant controls are suggested by the model in Section 3. The dividend yield was held fixed in the analysis there, but it is possible that firms may respond to tax changes by adjusting their payout policies. Thus, the dividend yield - also calculated using the updated version of Shiller's (1989) dataset, and defined as D/P (the aggregate measure of dividends, divided by the aggregate stock price measure, for a given year) - is included as a control variable. ${ }^{23}$ The corporate tax rate is also held fixed in the model, but an exogenous

\footnotetext{
${ }^{22}$ This is available at: http://www.econ.yale.edu/ shiller/data.htm; see also Shiller (2003).

${ }^{23}$ Stock repurchases are not included in the model. However, estimating the model over the 1929-1975 period, and hence excluding the years since the early 1980's when repurchases have become important, leads to consistent results (see below). Both $\mathrm{P} / \mathrm{E}$ and $\mathrm{D} / \mathrm{P}$ are expressed as ratios, and it is possible that their interpretation may be
} 
increase in this rate would increase the corporate tax preference for debt and lead to an equilibrium where a smaller fraction of investors hold equity. Thus, the top statutory corporate tax rate is included as a control. ${ }^{24}$ The capital gains tax rate is normalized to zero in the model in Section 3, but increases in this rate would reduce the personal tax preference for equity. Thus, two measures of the capital gains tax rate - the nominal statutory rate, and the effective statutory rate (which takes into account interactions with other elements of the tax code, such as the phaseout of itemized deductions) - are included as controls. ${ }^{25}$

The Herfindahl index constructed in Section 4 classifies taxpayers into income fractiles based on the distribution of income across taxpayers, rather than across the entire population (as the incomes of nonfilers are unobservable when using tax return data). This is unlikely to be a significant issue for the period since 1945 (over which the fraction of households filing returns has been large and relatively stable). However, relatively few households filed income tax returns in the period before WWII so the measure of stock ownership concentration may be affected by changes in the composition of the population of taxpayers, especially around WWII when the fraction of filers rose dramatically. This issue is addressed in two ways. First, a control is included for the fraction of households filing an income tax return, as calculated by Piketty and Saez (2003). Second, a test for robustness is carried out by omitting all years up to 1945 from the sample period.

The distribution of equity ownership may also be affected by general changes in wealth and income distribution. Because of a substantial number of missing observations in the measures of wealth distribution constructed by Kopczuk and Saez (2004) using estate tax return data, the measures of top income shares constructed by Piketty and Saez (2003) are used as controls for distribution. These series represent the shares of income received by the top $1 \%$, $0.1 \%$ and $0.01 \%$ of the income distribution, where income is defined to include capital gains. ${ }^{26}$

confounded by unrelated changes in the denominator. However, using the unscaled stock price, dividend and earnings series instead of these ratios leads to generally consistent results.

${ }^{24}$ These rates are obtained from U.S. Department of the Treasury (2003, Table 1), and represent the statutory tax rate on the top bracket of corporate income. Note that in some years, higher corporate tax rates may have applied inframarginally.

25 These rates are from Burman (1999, Table 2-4, pp. 26-27), and apply to long-term gains. The rates used for 193437 are based on the $70 \%$ exclusion for very long-term capital gains.

${ }^{26}$ The set of controls described above is not, of course, exhaustive. For example, Hong, Kubik and Stein (2004) identify social interactions as an important factor in stock market participation decisions. Such variables, however, are difficult to measure at the aggregate level. Other potentially important factors, such as the growth of financial 
The empirical specification used to investigate the effects of changes in the top statutory personal tax rate on changes in stock ownership distribution can be represented as follows: ${ }^{27}$

$$
\Delta C_{t}=\beta_{0}+\beta_{1}\left(\Delta T O P T A X_{t}\right)+\Delta \mathbf{T}_{\mathbf{t}} \boldsymbol{\beta}_{\mathbf{2}}+\Delta \mathbf{Z}_{\mathbf{t}} \boldsymbol{\beta}_{\mathbf{3}}+\mu_{t}
$$

where:

$\Delta C_{t}=\left(C_{t}-C_{t-1}\right)$ is the first-differenced stock ownership concentration index (i.e. the change in the concentration index from year $(t-1)$ to year $t)$

$\triangle T O P T A X_{t}$ is the first-differenced top statutory personal tax rate (i.e. the change in the rate from year $(t-1)$ to year $t)$

$\Delta \mathbf{T}_{\mathbf{t}}$ is a vector of changes in other personal tax rates (applicable to incomes of $\$ 50,000$, $\$ 100,000, \$ 250,000$ and $\$ 500,000$, all in 1999 dollars,)

$\Delta \mathbf{Z}_{\mathbf{t}}$ is a vector of changes in the following control variables: real GDP per capita, the P/E ratio, the dividend yield (D/P), the corporate tax rate, the nominal and effective capital gains tax rates, the fraction of households filing income tax returns, and the income shares of the top $1 \%, 0.1 \%$ and $0.01 \%$ of the population

$\mu_{t}$ is the error term (potentially subject to serial correlation and heteroskedasticity)

All variables are first-differenced in this specification, to avoid potential problems associated with nonstationarity. In particular, unit root tests (such as the modified Dickey-Fuller test proposed by Elliott, Rothenberg and Stock (1996)) fail to reject nonstationarity for the levels of the variables in Eq. (7). However, these tests reject the hypothesis of a unit root for each of the first-differenced variables. In addition (as discussed in Section 4 above), first-differencing minimizes the measurement problems that may arise from the use of dividends as a proxy for stock ownership.

A more detailed exploration of the changes in the patterns of stock ownership by different income categories involves analyzing the effects of the top tax rate on the ownership shares of particular subsets of the income distribution (in particular, the shares of each quintile of the

sophistication or the gradual diffusion of information about financial and tax innovations (e.g. tax-favored savings vehicles), are likely to be reflected in an overall time trend. This would primarily affect the level of concentration, rather than the changes that are examined here.

${ }^{27}$ An alternative empirical specification that uses as its independent variable the difference between the top tax rate and the other tax rates leads to generally consistent results. 
income distribution, as reported in Table 1). A secondary aim of this analysis is to test the hypothesis that higher rates of stock market participation are induced by strong market performance (e.g. Griffin et al., 2004). To this end, the specification includes (in addition to the top tax rate and the various controls discussed above) both contemporaneous and lagged changes in the $\mathrm{P} / \mathrm{E}$ ratio:

$$
\Delta s_{i t}=\beta_{0}+\beta_{1}\left(\Delta T O P T A X_{t}\right)+\Delta \mathbf{T}_{t} \boldsymbol{\beta}_{\mathbf{2}}+\Delta \mathbf{Z}_{\mathbf{t}} \boldsymbol{\beta}_{\mathbf{3}}+\beta_{4}\left(\Delta P E_{t-1}\right)+\mu_{i t}
$$

where

$\Delta s_{i t}=\left(s_{i t}-s_{i, t-1}\right)$ is the first-differenced share of corporate equity held by individuals in quintile $i$ of the income distribution, where $i=1,2, \ldots, 5$. The top quintile includes individuals between the $80^{\text {th }}$ and $100^{\text {th }}$ percentiles; the next includes individuals between the $60^{\text {th }}$ and $80^{\text {th }}$ percentiles, and the remaining quintiles are defined analogously

$\Delta \mathbf{T}_{\mathbf{t}}$ and $\Delta \mathbf{Z}_{\mathbf{t}}$ are defined as in Eq. (7)

$\triangle P E_{t-1}$ is the lagged first-differenced price-earnings ratio

$\mu_{i t}$ is the error term (potentially subject to serial correlation and heteroskedasticity)

While data on the concentration index $C_{t}$ is available from 1916, GDP data is only available from $1929{ }^{28}$ In addition, there are some missing observations for $C_{t}$ in the 1960 's. In total, there are 68 observations over the period 1929-2000 for which all the variables have nonmissing data; summary statistics calculated for this sample are reported in Table 2. However, all the regressions reported below use first differences rather than levels. First-differencing eliminates the first year of the sample, along with some additional years in the 1960's around the dates for which $C_{t}$ is missing. This results in a sample of 63 years over the period 1930-2000 for which the specifications above can be estimated.

\subsection{Results}

The basic strategy for estimating Eq's (7) and (8) involves using OLS on the firstdifferenced variables, as reported in Tables 3 and 5 . The procedure proposed by Newey and West (1987) is used to estimate standard errors that are robust to heteroskedasticity and to

\footnotetext{
${ }^{28}$ While this restriction reduces the sample size, it has some offsetting advantages. First, it eliminates the early period, when the reported data are arguably least reliable. Second, it excludes the episode of the WWI surtax that inspired the tax-based explanation of stock ownership dispersion developed by Means (1930); this enables a purely "out-of-sample" test of Means' hypothesis.
} 
autocorrelation of unknown form. An alternative maximum-likelihood approach that assumes first-order autocorrelation replicates this analysis in Table 4. Within each table, a base specification is provided for the whole sample period, along with analyses of subperiods to investigate the relevance of potentially confounding measurement issues.

The OLS results from the specification in Eq. (7) are presented in Column 1 of Table $3 .^{29}$ These results indicate that increases in the top personal tax rate have a significant negative effect on $C_{t}$, consistent with the hypothesis from Section 3. The estimated effect of the top tax rate on stock ownership concentration is of substantial magnitude. The coefficient on the top tax rate in Column 1 of Table 3 is approximately -0.16 , so that an increase in the top personal tax rate from its level at the end of the sample period (39.6\%) to the highest rate observed over that period (94\%) would result in a fall of about one standard deviation in the concentration index. Of course, this would represent a very large change in tax policy, but it should be remembered that there is a range of 70 percentage points $(24 \%$ to $94 \%)$ for the top tax rate in the sample used in the regression analysis (and a range of 87 percentage points for the entire 1916-2000 period). Thus, while the estimates suggest a large role for nontax factors, they also indicate that tax policy plays an important role in determining stock ownership concentration.

An alternative approach to estimating the model in Eq. (7) involves making more specific assumptions about the behavior of the disturbance term, in particular that $\mu_{t}$ is characterized by an AR(1) process: ${ }^{30}$

$$
\mu_{t}=\rho \mu_{t-1}+\varepsilon_{t}
$$

where $\rho$ is the first-order autocorrelation parameter, and the error term is $\varepsilon_{t} \sim \mathrm{N}\left(0, \sigma^{2}\right)$. Given the normality of $\varepsilon_{t}$, it is possible to estimate $\rho$ and the coefficients of Eq. (7) simultaneously using maximum-likelihood estimation. These estimates are presented in Column 1 of Table 4. The standard errors are calculated from the Hessian of the log-likelihood function. White's (1980) correction is used, so the standard errors are robust to symmetric non-normality of the error term

\footnotetext{
${ }^{29}$ The reported results use an autocorrelation structure with one lag, but generally consistent results are obtained using higher lags.

${ }^{30}$ Note that Eq. (9) applies to the residuals of the specification in Eq. (7), where the variables are first-differenced. If the model were to be specified in terms of levels, Eq. (9) entails that the residual in the levels equation would essentially follow a random walk, modified by the autocorrelation process. The residual in year $t$ would be a weighted sum of the contemporaneous $\varepsilon_{t}$ and all preceding $\varepsilon$ 's. This would be consistent with the nonstationarity of the Herfindahl index in levels (as suggested by the unit root tests discussed above).
} 
$\varepsilon_{t}$ and to heteroskedasticity of unknown form. The effect of the top statutory personal rate on stock ownership is very similar in magnitude to that estimated in Table 3 using OLS, and is unchanged in significance. The estimate of $\rho$ indicates a significant degree of negative autocorrelation (the sign is not surprising, as the data is first-differenced). The basic results are also robust to alternative specifications of the behavior of the disturbance term, for instance to adding a second-order autocorrelation term or a moving average term to Eq. (9). Thus, the findings from this maximum-likelihood approach are highly consistent with the OLS results in Table 3 .

Amongst the other control variables, it is worth noting that the price-earnings ratio has a negative effect in both Table 3 and Table 4, and is significant in the latter. This may provide some support for the notion that strong stock market performance induces higher levels of participation, thereby dispersing stock ownership. ${ }^{31}$ The main effect emphasized above is robust to the inclusion of capital gains tax rates and a control for the response of firms through dividend policy changes. These results rely on changes in statutory tax rates as a source of exogenous variation, so it does not appear likely that the measured tax rates are endogenous with respect to the amounts of income reported. Reverse causality (from ownership concentration, and more generally from changes in the distribution of wealth, to tax rate changes) cannot be completely ruled out. This would require, however, that decreased levels of ownership concentration lead to higher tax rates on the wealthy. While it is possible that such a mechanism is operative, it seems much more reasonable that political pressure for high top tax rates is likely to be greater when ownership is more concentrated.

Given the reliance on tax return data, it is important to consider the potentially confounding nature of changes in reporting behavior. The fraction of the population filing income tax returns has a positive effect, which is significant in Table 4. It would appear that increases in this fraction have a compositional effect, introducing into the observed population of taxpayers new households that hold little if any equity. This makes equity ownership appear to become more concentrated, as happens in the data around WWII (see Table 1). While the basic results control for changes in the fraction of filers, an alternative test of robustness is to exclude

\footnotetext{
${ }^{31}$ Of course, the result may also reflect reverse causality, with higher levels of participation leading buyers to bid up the price of stocks. Adding the lagged change in the price-earnings ratio to the model (in order to capture lags in the participation decision) does not significantly change any of the results, and the lagged term itself is insignificant. The effect of the price-earnings ratio is discussed in more detail below in the context of the results from Eq. (8).
} 
the period up to 1945, when the fraction of filers was much smaller than in the subsequent years. In addition, this test addresses the concern that the negative relationship between tax progressivity and ownership concentration may be driven by factors peculiar to the 1930's. The results for the 1946-2000 period are reported in Column 2 of Table 3 (using OLS) and Column 2 of Table 4 (using MLE). In Table 3, the coefficient of the top tax rate in Column 2 is virtually identical in magnitude to that in Column 1; however (perhaps due to reduced sample size), the standard error is much larger, and the effect is insignificant. In Table 4, on the other hand, the effect in Column 2 is significant. ${ }^{32}$ The robustness of these results to controls for filing as well as this additional analysis suggests that the basic results over the 1929-2000 period are not driven by the increase in the fraction of the population filing tax returns during WWII, nor by conditions specific to the 1930's.

It was noted in Section 4 that the stock ownership concentration index closely tracks a measure of equity ownership based on estate tax return data until about 1975; however, the two measures diverge after that point. To test whether the results are driven by possible mismeasurement of ownership over the period after 1975, these years are omitted from the sample period. This exclusion also addresses two additional possibly confounding factors. Both the growth of share repurchases since the early 1980's (e.g. Dittmar, 2000) and the growth of tax-favored investment accounts over the same period may affect the results by reducing the tax burden on equity. The results for the 1929-1975 period are reported in Column 3 of Table 3 (using OLS) and Column 3 of Table 4 (using MLE). The results are highly robust, with the effect of the top tax rate being negative and significant, and indeed are stronger than over the entire 1929-2000 period.

The results discussed so far show that taxes have a significant impact on the summary measure of stock ownership concentration. However, this does not in itself shed much light on which specific income groups change their holdings of corporate equity in response to tax changes. Addressing this question involves estimating Eq. (8), the results from which (using OLS with Newey-West standard errors) are shown in Table 5. The analysis focuses on quintiles of the income distribution and the results reported in Columns 1-5 are ordered from the top to the bottom of the income distribution. The results here are highly consistent with a tax-based

\footnotetext{
${ }^{32}$ The magnitude is substantially larger than that in Column 1, but the small sample size makes it difficult to conclude that the effect is necessarily larger over this period.
} 
explanation. For the top quintile, there is a negative and significant effect of the top tax rate on the share of equity ownership. In contrast, this effect is positive for all the other quintiles, and is significant for the second and third quintiles. The effect is positive but insignificant for the fourth quintile. Unsurprisingly, the ownership share of the lowest quintile is extremely noisy, and the regressors are jointly insignificant.

The results from Eq. (8) can also be used to test the hypothesis that stronger stock market performance leads (possibly with some lag) to increased rates of participation, and hence to greater dispersion of ownership. The specification in Eq. (8) includes changes in both the current and lagged $\mathrm{P} / \mathrm{E}$ ratios as measures of stock market performance. Generally, the effects are insignificant, and vary in sign. It is worth noting that the effects of the contemporaneous $\mathrm{P} / \mathrm{E}$ ratio on the shares of the top and second quintiles are negative and positive, respectively, and are close to borderline significance. In addition, the positive effect of the lagged change in the $\mathrm{P} / \mathrm{E}$ ratio on the ownership share of the fourth quintile is of borderline significance. Combined with the results for the $\mathrm{P} / \mathrm{E}$ ratio in Table 4, this suggests a limited role for market performance and valuation levels in determining participation.

\section{Conclusion}

Changes in the progressivity of the U.S. tax system during the twentieth century appear to have influenced aggregate stock ownership concentration and equity market participation. These results do not appear to reflect a variety of potentially confounding measurement issues or other economic mechanisms. The logic of Berle and Means (1932), as embodied in an extension of Miller (1977), appears to help explain corporate ownership patterns throughout the century.

The finding that tax progressivity influences ownership concentration also links this paper to the broader literature on the rationales for progressive taxes. Since Mirrlees (1971), characterizations of optimal income tax schedules that take account of incentive effects on labor supply generally find that the optimal income tax schedule is close to linear. Slemrod et al. (1994) analyze a piecewise linear two-bracket tax structure, and find that, under fairly general conditions, the marginal tax rate is lower in the segment of the tax schedule applicable at higher incomes (although the optimal tax structure involves progressivity in terms of average tax rates). Thus, Slemrod (2000, p. 11) concludes that: "In sum, simple models of optimal income taxation do not necessarily point to sharply progressive tax structures, even if the objective function puts 
relatively large weight on the welfare of less well-off individuals." Further analyses could integrate the influence of taxes on ownership concentration and equity market participation into an optimal tax framework.

Because this study only analyzes data from one country, it is not necessarily possible to extrapolate these findings to other contexts. In particular, progressive taxation should not be considered a sufficient condition for corporate ownership diffusion. Rather, tax progressivity is likely to interact with investor protections and other factors that affect agency costs. For instance, a progressive tax structure alone is not likely to lead to diffuse ownership unless investor protections are strong. Further analysis of time-series properties of ownership concentration in other countries, along with cross-country studies, could usefully illuminate such links.

The links between taxation and ownership concentration open up several further lines of inquiry. The analysis above has focused primarily on the aggregate time-series analysis of changes in the summary measure of ownership concentration. It may be possible to shed more light on the dynamics of the portfolio reallocations induced by tax changes by constructing a synthetic panel of income fractiles or by examining specific tax reforms and their effects through other data sources. This would enable a more precise specification of the tax characteristics of each fractile in any given year, and reveal how each fractile's ownership patterns change in response to changes in the marginal tax rate that it faces. There are also a number of additional controls - such as measures of financial sophistication and investor protections - that could be incorporated into the analysis, especially if it were extended to a cross-country setting. 


\section{References}

Auerbach, A. J. (2002) "Taxation and Corporate Financial Policy" in A. J. Auerbach and M. Feldstein (eds.) Handbook of Public Economics, Vol. 3, Amsterdam: Elsevier, 12511292.

Auerbach, A. J., L. E. Burman and J. M. Siegel (2000) "Capital Gains Taxation and Tax Avoidance: New Evidence from Panel Data" in J. Slemrod (ed.) Does Atlas Shrug? The Economic Consequences of Taxing the Rich Cambridge, MA: Harvard University Press, 355-388.

Auerbach, A. J. and M. A. King (1983) "Taxation, Portfolio Choice, and Debt-Equity Ratios: A General Equilibrium Model” Quarterly Journal of Economics, 98, 587-609.

Becht, M. and B. Delong (2004) "Why Has There Been So Little Blockholding in the U.S.?" Working Paper.

Berle, A. A., Jr., and G. C. Means (1932) The Modern Corporation and Private Property New York: The Macmillan Company.

Brav, A., J. R. Graham, C. Harvey, and R. Michaely (2005) "Payout Policy in the $21^{\text {st }}$ Century" Journal of Financial Economics, forthcoming.

Brown, J. R., N. Liang and S. Weisbenner (2004) "Executive Financial Incentives and Payout Policy: Firm Responses to the 2003 Dividend Tax Cut” NBER Working Paper \#11002.

Brownlee, W. E. (1996) Federal Taxation in America: A Short History New York: Cambridge University Press.

Burman, L. E. (1999) The Labyrinth of Capital Gains Tax Policy: A Guide for the Perplexed Washington, DC: Brookings Institution Press.

Chetty, R. and E. Saez (2004) "Dividend Taxes and Corporate Behavior: Evidence from the 2003 Dividend Tax Cut” NBER Working Paper \#10841.

Curcuru, S., J. Heaton, D. Lucas and D. Moore (2004) "Heterogeneity and Portfolio Choice: Theory and Evidence" Working Paper, Northwestern University.

Dammon, R. M., C. S. Spatt and H. H. Zhang (2004) "Optimal Asset Location and Allocation with Taxable and Tax-Deferred Investing” Journal of Finance, 59, 999-1037.

Desai, M. A. and D. Dharmapala (2005a) "Corporate Tax Avoidance and High Powered Incentives” Journal of Financial Economics, forthcoming.

Desai, M. A. and D. Dharmapala (2005b) “Corporate Tax Avoidance and Firm Value" NBER Working Paper \#11241. 
Desai, M. A., A. Dyck, and L. Zingales (2004) “Theft and Taxation” NBER Working Paper $\# 10978$.

Dittmar, A. K. (2000) “Why Do Firms Repurchase Stock?” Journal of Business, 73, 331-355.

Elliott, G., T. Rothenberg and J. H. Stock (1996) "Efficient Tests for an Autoregressive Unit Root" Econometrica, 64, 813-836.

Fama, E. F. and K. R. French (2001) "Disappearing Dividends: Changing Firm Characteristics or Lower Propensity to Pay?” Journal of Financial Economics, 60, 3-44.

Franks, J. R., C. Mayer and S. Rossi (2003) “Ownership: Evolution and Regulation” ECGI Working Paper 09/2003.

Griffin, J. M., F. Nardari and R. M. Stulz (2004) "Stock Market Trading and Market Conditions" NBER Working Paper \#10719.

Haliassos, M. and C. Bertaut (1995) "Why Do So Few Hold Stocks?” Economic Journal, 105, $1110-1129$.

Hong, H., J. D. Kubik and J. C. Stein (2004) "Social Interaction and Stock-Market Participation" Journal of Finance, 59, 137-163.

Kakwani, N. C. (1977) "Applications of Lorenz Curves in Economic Analysis” Econometrica, $45,719-727$.

Kopczuk, W. and E. Saez (2004) "Top Wealth Shares in the United States, 1916-2000: Evidence from Estate Tax Returns" National Tax Journal, 57, 445-487.

Kuznets, S. (1953) Shares of Upper Income Groups in Income and Savings New York: National Bureau of Economic Research.

La Porta, R., F. Lopez-de-Silanes, A. Shleifer and R. W. Vishny (1998) "Law and Finance" Journal of Political Economy, 106, 1113-1155.

Lintner, J. (1956) "Distribution of Incomes of Corporations among Dividends, Retained Earnings, and Taxes" American Economic Review, 46, 97-113.

Mallet, B. (1908) “A Method of Estimating Capital Wealth from Estate Duty Statistics.” Journal of the Royal Statistical Society, 71, 65-101.

Means, G. C. (1930) “The Diffusion of Stock Ownership in the United States” Quarterly Journal of Economics, 44, 561-600.

Miller, M. H. (1977) “Debt and Taxes” Journal of Finance, 32, 261-275. 
Mirrlees, J. A. (1971) “An Exploration in the Theory of Optimum Income Taxation” Review of Economic Studies, 38, 175-208.

Morck, R. (2004) "How to Eliminate Pyramidal Business Groups - The Double Taxation of Inter-Corporate Dividends and Other Incisive Uses of Tax Policy" NBER Working Paper \#10944.

Morck, R., M. Percy, G. Tian and B. Yeung (2004) "The Rise and Fall of the Widely Held Firm: A History of Corporate Ownership in Canada" NBER Working Paper \#10635.

Morck, R. and L. Steier (2005) "The Global History of Corporate Governance - An Introduction” NBER Working Paper \#11062.

Musgrave, R. A. (1992) "Schumpeter's Crisis of the Tax State: An Essay in Fiscal Sociology" Journal of Evolutionary Economics, 2, 89-113.

Newey, W. K. and K. West (1987) "A Simple Positive Semi-Definite, Heteroscedasticity and Autocorrelation Consistent Covariance Matrix” Econometrica, 55, 703-708.

Perez-Gonzales, F. (2003) "Large Shareholders and Dividends: Evidence from U.S. Tax Reforms" Working paper.

Piketty, T. and E. Saez (2003) "Income Inequality in the United States, 1913-1998” Quarterly Journal of Economics, 118, 1-39.

Poterba, J. (2001) “Taxation and Portfolio Structure: Issues and Implications" NBER Working Paper \#8223.

Rajan R. G. and L. Zingales (2003) "The Great Reversals: The Politics of Financial Development in the Twentieth Century," Journal of Financial Economics, 69, 5-50.

Ratner, S. (1942) American Taxation: Its History as a Social Force in Democracy New York: Norton.

Roe, M. J. (1994) Strong Managers, Weak Owners: The Political Roots of American Corporate Finance Princeton, N.J.: Princeton University Press.

Roe, M. J. (2002) “Corporate Law’s Limits” Journal of Legal Studies, 31, 233-271.

Seligman, E. R. A. (1911) The Income Tax: A Study of the History, Theory and Practice of Income Taxation at Home and Abroad New York: The Macmillan Company.

Shiller, R. J. (1989) Market Volatility Cambridge, MA and London: MIT Press. 
Shiller, R. J. (2003) "From Efficient Markets Theory to Behavioral Finance" Journal of Economic Perspectives, 17, 83-104.

Shoven, J. B. and C. Sialm (2004) "Asset Location in Tax-Deferred and Conventional Savings Accounts" Journal of Public Economics, 88, 23-38.

Sialm, C. (2003) “Tax Changes and Asset Returns: An Empirical Investigation” Working paper.

Slemrod, J. (2000) "The Economics of Taxing the Rich" in J. Slemrod (ed.) Does Atlas Shrug? The Economic Consequences of Taxing the Rich Cambridge, MA: Harvard University Press, 3-28.

Slemrod, J., S. Yitzhaki, J. Mayshar and M. Lundholm (1994) "The Optimal Two-Bracket Linear Income Tax” Journal of Public Economics, 53, 269-90.

U.S. Department of the Treasury, Internal Revenue Service, Statistics of Income: Estate and Gift Tax Returns, various years.

U.S. Department of the Treasury, Internal Revenue Service, Statistics of Income: Individual Income Tax Returns, various years.

U.S. Department of the Treasury (2003) "Corporation Income Tax Brackets and Rates, 19092002” Internal Revenue Service, Statistics of Income Bulletin, Fall 2003.

Vissing-Jorgensen, A. (2002) "Towards an Explanation of Household Portfolio Choice Heterogeneity: Nonfinancial Income and Participation Cost Structures" NBER Working Paper \#8884.

Warshow, H. T. (1924) "The Distribution of Corporate Ownership in the United States" Quarterly Journal of Economics, 39, 15-38.

White, H. (1980) "A Heteroskedasticity-Consistent Covariance Matrix Estimator and a Direct Test for Heteroskedasticity" Econometrica, 48, 817-830. 
Figure 1: Changes in Tax Progressivity and Financial Market Equilibrium

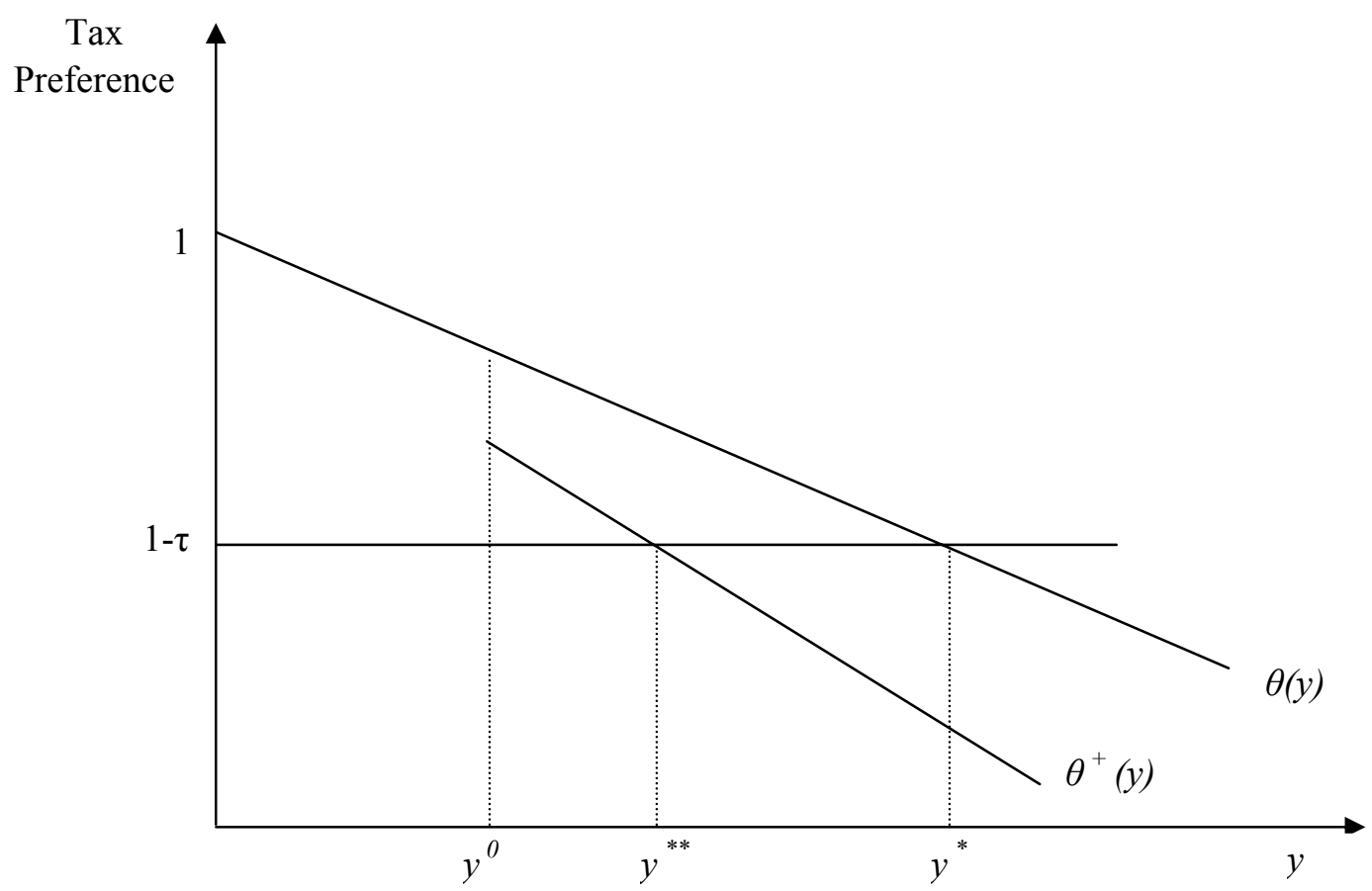

Figure 2: Herfindahl Index of the Concentration of U.S. Stock Ownership 1916-2000

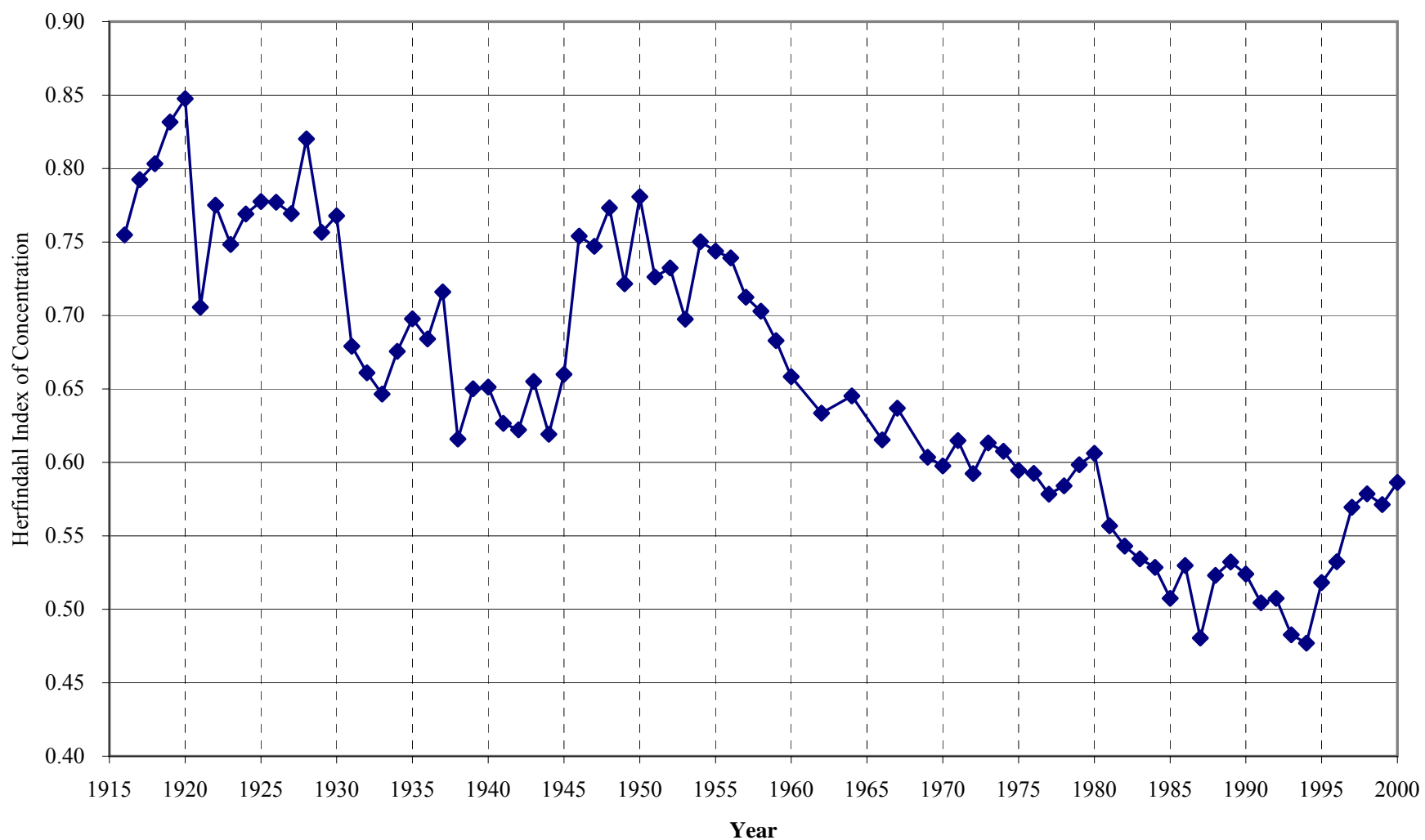

Notes: The figure plots the Herfindahl index of corporate ownership that is constructed on the basis of the dividend shares of income quintiles. 
Figure 3: A Comparison of the Estate Tax Equity Series with the Herfindahl Index of Ownership Concentration 1916-2000

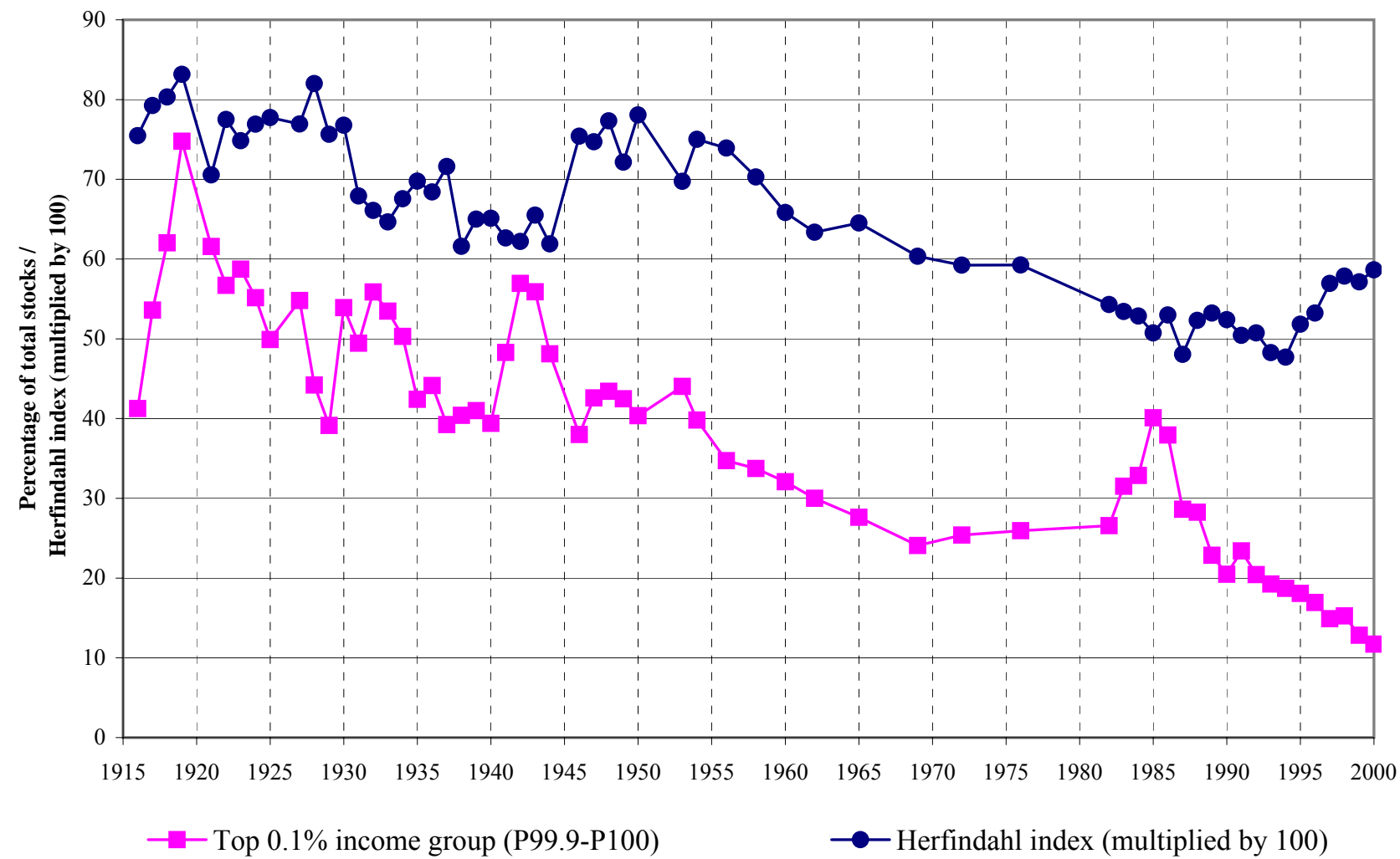

Notes: The figure compares the Herfindahl index of corporate ownership that is constructed on the basis of the dividend shares of income quintiles with the equity series for the top $0.1 \%$ group based on estate tax return data. 
Table 1: Dividend shares for different income fractiles and the Herfindahl index of concentration of stock ownership 1916-2000

\begin{tabular}{|c|c|c|c|c|c|c|c|c|}
\hline Year & $\begin{array}{c}\text { P0-P20 } \\
\text { (1) }\end{array}$ & $\begin{array}{c}\text { P20-P40 } \\
\text { (2) }\end{array}$ & $\begin{array}{c}\text { P40-P60 } \\
\text { (3) }\end{array}$ & $\begin{array}{c}\text { P60-P80 } \\
(4)\end{array}$ & $\begin{array}{c}\text { P80-P100 } \\
(5) \\
\end{array}$ & $\begin{array}{c}\text { Herfindahl } \\
\text { index } \\
(6) \\
\end{array}$ & $\begin{array}{c}\text { Top } 10 \% \\
\text { P90-P100 } \\
(7) \\
\end{array}$ & $\begin{array}{c}\text { Top 1\% } \\
\text { P99-P100 } \\
\text { (8) }\end{array}$ \\
\hline 1916 & 1.15 & 0.95 & 2.82 & 8.70 & 86.38 & 0.7548 & 78.53 & 42.78 \\
\hline 1917 & 1.12 & 1.53 & 2.74 & 5.85 & 88.77 & 0.7925 & 79.15 & 41.70 \\
\hline 1918 & 1.13 & 1.43 & 2.18 & 4.44 & 89.47 & 0.8032 & 82.19 & 55.59 \\
\hline 1919 & 0.98 & 1.24 & 2.32 & 4.41 & 91.04 & 0.8316 & 86.02 & 48.66 \\
\hline 1920 & 1.08 & 1.23 & 2.02 & 3.73 & 91.95 & 0.8475 & 90.09 & 50.08 \\
\hline 1921 & 7.82 & 1.46 & 2.23 & 3.58 & 83.52 & 0.7056 & 78.89 & 50.68 \\
\hline 1922 & 4.73 & 1.23 & 2.27 & 3.98 & 87.78 & 0.7750 & 84.94 & 48.36 \\
\hline 1923 & 2.19 & 1.88 & 2.93 & 5.64 & 86.22 & 0.7483 & 82.69 & 45.61 \\
\hline 1924 & 2.00 & 1.74 & 3.08 & 5.77 & 87.41 & 0.7691 & 86.28 & 55.80 \\
\hline 1925 & 1.24 & 1.90 & 3.22 & 5.75 & 87.90 & 0.7775 & 81.22 & 40.45 \\
\hline 1926 & 1.28 & 1.57 & 3.32 & 5.98 & 87.86 & 0.7770 & 81.34 & 41.72 \\
\hline 1927 & 2.98 & 2.98 & 2.98 & 3.57 & 87.48 & 0.7693 & 82.02 & 45.03 \\
\hline 1928 & 2.09 & 2.09 & 2.09 & 3.31 & 90.43 & 0.8201 & 83.23 & 43.91 \\
\hline 1929 & 3.02 & 3.02 & 3.02 & 4.21 & 86.72 & 0.7565 & 79.23 & 47.66 \\
\hline 1930 & 2.98 & 2.98 & 2.98 & 3.66 & 87.40 & 0.7678 & 77.47 & 44.84 \\
\hline 1931 & 4.17 & 4.17 & 4.17 & 4.17 & 81.98 & 0.6790 & 71.74 & 40.38 \\
\hline 1932 & 4.82 & 4.82 & 4.82 & 4.82 & 80.72 & 0.6609 & 79.81 & 51.95 \\
\hline 1933 & 5.06 & 5.06 & 5.06 & 5.06 & 79.77 & 0.6465 & 79.73 & 52.87 \\
\hline 1934 & 4.32 & 4.32 & 4.32 & 4.32 & 81.74 & 0.6755 & 76.45 & 44.14 \\
\hline 1935 & 4.23 & 4.23 & 4.23 & 4.23 & 83.10 & 0.6977 & 78.87 & 49.05 \\
\hline 1936 & 4.25 & 4.25 & 4.25 & 4.25 & 82.27 & 0.6840 & 80.09 & 44.23 \\
\hline 1937 & 3.00 & 2.31 & 4.11 & 5.86 & 84.23 & 0.7160 & 76.54 & 47.87 \\
\hline 1938 & 6.38 & 2.86 & 6.19 & 6.92 & 77.62 & 0.6159 & 74.69 & 44.76 \\
\hline 1939 & 5.71 & 3.01 & 4.88 & 6.44 & 79.96 & 0.6500 & 76.72 & 48.13 \\
\hline 1940 & 6.08 & 4.56 & 4.13 & 5.04 & 80.07 & 0.6512 & 77.70 & 49.43 \\
\hline 1941 & 7.12 & 4.53 & 4.33 & 5.64 & 78.38 & 0.6265 & 77.98 & 39.79 \\
\hline 1942 & 6.68 & 4.59 & 4.26 & 6.39 & 78.08 & 0.6221 & 75.64 & 40.79 \\
\hline 1943 & 6.16 & 4.25 & 4.52 & 4.75 & 80.32 & 0.6550 & 77.34 & 45.88 \\
\hline 1944 & 3.77 & 5.47 & 5.75 & 7.14 & 77.86 & 0.6191 & 71.82 & 46.78 \\
\hline 1945 & 2.32 & 4.88 & 5.29 & 6.93 & 80.59 & 0.6599 & 74.01 & 47.80 \\
\hline 1946 & 1.74 & 3.23 & 3.41 & 5.08 & 86.54 & 0.7540 & 81.90 & 54.54 \\
\hline 1947 & 2.16 & 3.52 & 3.60 & 4.58 & 86.13 & 0.7470 & 83.87 & 56.51 \\
\hline 1948 & 2.06 & 3.01 & 2.99 & 4.24 & 87.70 & 0.7732 & 82.12 & 58.73 \\
\hline 1949 & 2.12 & 3.68 & 3.98 & 5.67 & 84.55 & 0.7215 & 78.31 & 53.30 \\
\hline 1950 & 2.49 & 2.07 & 3.10 & 2.38 & 88.21 & 0.7807 & 85.13 & 62.56 \\
\hline 1951 & 1.73 & 3.29 & 3.69 & 6.48 & 84.81 & 0.7262 & 80.55 & 61.38 \\
\hline 1952 & 2.03 & 3.61 & 4.00 & 5.13 & 85.23 & 0.7324 & 81.56 & 59.94 \\
\hline 1953 & 2.50 & 4.59 & 4.23 & 5.63 & 83.05 & 0.6974 & 79.20 & 56.86 \\
\hline 1954 & 1.52 & 3.48 & 3.48 & 5.21 & 86.30 & 0.7502 & 83.49 & 63.79 \\
\hline 1955 & 1.61 & 3.17 & 3.85 & 5.46 & 85.91 & 0.7438 & 82.01 & 54.48 \\
\hline 1956 & 1.43 & 3.41 & 3.79 & 5.76 & 85.62 & 0.7392 & 79.73 & 56.63 \\
\hline 1957 & 1.76 & 4.00 & 4.13 & 6.15 & 83.96 & 0.7123 & 78.89 & 55.38 \\
\hline 1958 & 1.60 & 4.03 & 4.57 & 6.45 & 83.35 & 0.7029 & 79.38 & 55.01 \\
\hline 1959 & 1.89 & 4.55 & 4.52 & 6.97 & 82.07 & 0.6829 & 76.15 & 57.23 \\
\hline 1960 & 2.00 & 5.48 & 5.04 & 7.03 & 80.46 & 0.6582 & 75.64 & 55.30 \\
\hline 1962 & 2.37 & 5.53 & 6.18 & 7.12 & 78.81 & 0.6335 & 73.04 & 47.43 \\
\hline
\end{tabular}


Table 1: Dividend shares for different income fractiles and the Herfindahl index of concentration of stock ownership 1916-2000

\begin{tabular}{|c|c|c|c|c|c|c|c|c|}
\hline Year & $\begin{array}{l}\text { P0-P20 } \\
\text { (1) } \\
\end{array}$ & $\begin{array}{c}\text { P20-P40 } \\
\text { (2) }\end{array}$ & $\begin{array}{c}\text { P40-P60 } \\
\text { (3) }\end{array}$ & $\begin{array}{c}\text { P60-P80 } \\
\text { (4) }\end{array}$ & $\begin{array}{c}\text { P80-P100 } \\
(5)\end{array}$ & $\begin{array}{l}\text { Herfindahl } \\
\text { index } \\
(6)\end{array}$ & $\begin{array}{c}\text { Top 10\% } \\
\text { P90-P100 } \\
(7)\end{array}$ & $\begin{array}{c}\text { Top 1\% } \\
\text { P99-P100 } \\
(8)\end{array}$ \\
\hline 1964 & 2.17 & 5.24 & 6.12 & 6.87 & 79.59 & 0.6452 & 73.52 & 47.39 \\
\hline 1966 & 2.45 & 4.61 & 6.61 & 8.85 & 77.48 & 0.6153 & 71.46 & 46.58 \\
\hline 1967 & 2.25 & 4.66 & 6.52 & 7.56 & 79.00 & 0.6368 & 72.36 & 46.80 \\
\hline 1969 & 2.33 & 4.70 & 6.22 & 10.16 & 76.59 & 0.6035 & 70.59 & 44.33 \\
\hline 1970 & 2.38 & 6.22 & 6.71 & 8.44 & 76.25 & 0.5975 & 70.21 & 42.15 \\
\hline 1971 & 2.62 & 5.71 & 4.96 & 9.25 & 77.45 & 0.6148 & 70.02 & 42.82 \\
\hline 1972 & 2.38 & 5.83 & 7.71 & 8.21 & 75.87 & 0.5923 & 68.95 & 41.45 \\
\hline 1973 & 2.50 & 4.76 & 7.02 & 8.36 & 77.36 & 0.6133 & 70.11 & 41.03 \\
\hline 1974 & 2.51 & 5.10 & 6.95 & 8.48 & 76.96 & 0.6076 & 71.64 & 41.14 \\
\hline 1975 & 2.85 & 4.80 & 7.16 & 9.17 & 76.02 & 0.5945 & 67.75 & 40.70 \\
\hline 1976 & 2.24 & 4.77 & 7.85 & 9.31 & 75.82 & 0.5925 & 67.79 & 40.18 \\
\hline 1977 & 2.00 & 5.05 & 7.36 & 10.89 & 74.70 & 0.5783 & 67.96 & 40.10 \\
\hline 1978 & 2.43 & 4.96 & 7.43 & 9.97 & 75.20 & 0.5841 & 66.77 & 39.35 \\
\hline 1979 & 2.23 & 4.28 & 7.47 & 9.81 & 76.21 & 0.5984 & 68.13 & 40.81 \\
\hline 1980 & 2.29 & 4.21 & 6.80 & 9.93 & 76.77 & 0.6061 & 67.97 & 39.49 \\
\hline 1981 & 2.91 & 4.89 & 7.85 & 11.23 & 73.12 & 0.5567 & 63.69 & 35.57 \\
\hline 1982 & 3.28 & 4.97 & 7.87 & 11.82 & 72.06 & 0.5430 & 63.30 & 35.55 \\
\hline 1983 & 3.14 & 5.21 & 8.26 & 12.03 & 71.36 & 0.5343 & 62.05 & 35.80 \\
\hline 1984 & 3.21 & 5.05 & 9.47 & 11.35 & 70.93 & 0.5285 & 60.90 & 32.97 \\
\hline 1985 & 3.53 & 5.07 & 9.90 & 12.32 & 69.18 & 0.5074 & 59.85 & 34.51 \\
\hline 1986 & 3.42 & 4.36 & 9.55 & 11.68 & 70.99 & 0.5298 & 60.97 & 35.37 \\
\hline 1987 & 3.60 & 5.45 & 9.96 & 14.19 & 66.79 & 0.4805 & 55.94 & 28.40 \\
\hline 1988 & 2.86 & 5.74 & 8.58 & 12.37 & 70.45 & 0.5230 & 60.99 & 35.45 \\
\hline 1989 & 2.97 & 5.29 & 8.20 & 12.37 & 71.17 & 0.5322 & 60.66 & 33.71 \\
\hline 1990 & 3.36 & 5.61 & 7.92 & 12.57 & 70.55 & 0.5240 & 60.18 & 34.21 \\
\hline 1991 & 3.62 & 5.94 & 8.39 & 13.12 & 68.94 & 0.5044 & 57.88 & 31.47 \\
\hline 1992 & 3.66 & 5.75 & 8.88 & 12.49 & 69.23 & 0.5075 & 57.68 & 31.82 \\
\hline 1993 & 3.80 & 6.28 & 8.89 & 13.96 & 67.07 & 0.4827 & 55.67 & 29.54 \\
\hline 1994 & 4.27 & 7.11 & 8.90 & 12.99 & 66.73 & 0.4770 & 56.98 & 30.34 \\
\hline 1995 & 4.01 & 5.99 & 7.96 & 11.86 & 70.19 & 0.5182 & 58.52 & 31.48 \\
\hline 1996 & 3.43 & 5.65 & 7.36 & 12.34 & 71.23 & 0.5324 & 60.82 & 32.70 \\
\hline 1997 & 3.04 & 4.75 & 6.97 & 11.14 & 74.09 & 0.5694 & 63.12 & 32.34 \\
\hline 1998 & 3.00 & 4.52 & 6.22 & 11.54 & 74.73 & 0.5785 & 63.18 & 34.55 \\
\hline 1999 & 2.96 & 4.33 & 5.98 & 12.63 & 74.09 & 0.5713 & 62.82 & 34.30 \\
\hline 2000 & 3.05 & 4.28 & 5.63 & 11.77 & 75.27 & 0.5864 & 69.47 & 39.86 \\
\hline
\end{tabular}

Note: The columns provide quintile shares that are summarized in the Herfindahl index. The last two columns provide the share for the top $10 \%$ and top $1 \%$. 
Table 2

\section{Summary Statistics}

\begin{tabular}{|c|c|c|c|}
\hline & Mean & $\begin{array}{l}\text { Standard } \\
\text { Deviation }\end{array}$ & $\begin{array}{c}\text { Number of } \\
\text { Observations }\end{array}$ \\
\hline Stock Ownership Concentration Index & 0.6266 & 0.0822 & 68 \\
\hline Top Statutory Personal Tax Rate & 0.6595 & 0.2205 & 68 \\
\hline $\begin{array}{l}\text { Personal Tax Rate at Income }=\$ 500,000 \text { (in } \\
1999 \text { dollars) }\end{array}$ & 0.4946 & 0.1806 & 68 \\
\hline $\begin{array}{l}\text { Personal Tax Rate at Income }=\$ 250,000 \text { (in } \\
1999 \text { dollars) }\end{array}$ & 0.4003 & 0.1568 & 68 \\
\hline $\begin{array}{l}\text { Personal Tax Rate at Income }=\$ 100,000 \text { (in } \\
1999 \text { dollars) }\end{array}$ & 0.2451 & 0.1047 & 68 \\
\hline $\begin{array}{l}\text { Personal Tax Rate at Income }=\$ 50,000 \text { (in } \\
1999 \text { dollars) }\end{array}$ & 0.1618 & 0.0749 & 68 \\
\hline $\begin{array}{l}\text { Share of Corporate Equity held by the Top } \\
\text { Quintile }\end{array}$ & 77.9846 & 5.8116 & 68 \\
\hline $\begin{array}{l}\text { Share of Corporate Equity held by the 2nd- } \\
\text { Highest Quintile }\end{array}$ & 8.2382 & 3.1612 & 68 \\
\hline $\begin{array}{l}\text { Share of Corporate Equity held by the 3rd- } \\
\text { Highest Quintile }\end{array}$ & 5.9779 & 1.9681 & 68 \\
\hline $\begin{array}{l}\text { Share of Corporate Equity held by the 4th- } \\
\text { Highest Quintile }\end{array}$ & 4.5750 & 0.9998 & 68 \\
\hline $\begin{array}{l}\text { Share of Corporate Equity held by the Lowes } \\
\text { Quintile }\end{array}$ & 3.1446 & 1.3027 & 68 \\
\hline $\begin{array}{l}\text { Real GDP per capita (in thousands of } 2000 \\
\text { dollars) }\end{array}$ & 17.6321 & 8.4285 & 68 \\
\hline Price-Earnings Ratio & 14.9237 & 5.4945 & 68 \\
\hline Dividend Yield (multiplied by 100) & 4.4013 & 1.4500 & 68 \\
\hline Corporate Tax Rate & 0.3864 & 0.1266 & 68 \\
\hline Capital Gains Tax Rate & 0.2433 & 0.0593 & 68 \\
\hline Effective Capital Gains Tax Rate & 0.2588 & 0.0885 & 68 \\
\hline Fraction of Households Filing a Tax Return & 0.7596 & 0.3153 & 68 \\
\hline Income Share of Top 1\% & 13.1468 & 3.3396 & 68 \\
\hline Income Share of Top $0.1 \%$ & 4.9491 & 1.9638 & 68 \\
\hline Income Share of Top $0.01 \%$ & 1.8693 & 0.9452 & 68 \\
\hline
\end{tabular}

Note: The variables are as defined in the text. Note that these summary statistics are for the 68 observations over the period 1929-2000 that are used in the regression analysis reported in Tables 3-5. 
Table 3

Taxes and Stock Ownership Concentration: OLS Results with Newey-West Standard Errors

Dependent Variable:

\begin{tabular}{|c|c|c|c|}
\hline & (1) & (2) & (3) \\
\hline Constant & $\begin{array}{r}-0.0013 \\
(0.0043)\end{array}$ & $\begin{array}{r}-0.0011 \\
(0.0045)\end{array}$ & $\begin{array}{r}0.0016 \\
(0.0058)\end{array}$ \\
\hline $\begin{array}{l}\text { Change in Top Statutory Personal } \\
\text { Tax Rate }\end{array}$ & $\begin{array}{l}-0.1617 * * \\
(0.0711)\end{array}$ & $\begin{array}{r}-0.1751 \\
(0.3620)\end{array}$ & $\begin{array}{l}-0.2103 * * \\
(0.0877)\end{array}$ \\
\hline Change in real GDP per capita & $\begin{array}{r}-0.0064 \\
(0.0090)\end{array}$ & $\begin{array}{r}-0.0066 \\
(0.0074)\end{array}$ & $\begin{array}{r}-0.0091 \\
(0.0095)\end{array}$ \\
\hline Change in Price-Earnings Ratio & $\begin{array}{r}-0.0016 \\
(0.0014)\end{array}$ & $\begin{array}{l}-0.0019 * \\
(0.0011)\end{array}$ & $\begin{array}{r}-0.0022 \\
(0.0027)\end{array}$ \\
\hline Change in Dividend Yield & $\begin{array}{r}-0.0128 \\
(0.0082)\end{array}$ & $\begin{array}{r}-0.0032 \\
(0.0074)\end{array}$ & $\begin{array}{r}-0.0194 \\
(0.0136)\end{array}$ \\
\hline Change in Corporate Tax Rate & $\begin{array}{c}0.0794 \\
(0.2437)\end{array}$ & $\begin{array}{c}0.2056 \\
(0.3445)\end{array}$ & $\begin{array}{c}0.2054 \\
(0.3509)\end{array}$ \\
\hline $\begin{array}{l}\text { Change in Capital Gains Tax } \\
\text { Rate }\end{array}$ & $\begin{array}{c}0.4070 \\
(0.2890)\end{array}$ & $\begin{array}{r}-0.0334 \\
(0.3870)\end{array}$ & $\begin{array}{l}1.1346 * \\
(0.5975)\end{array}$ \\
\hline $\begin{array}{l}\text { Change in Effective Capital } \\
\text { Gains Tax Rate }\end{array}$ & $\begin{array}{l}-0.2221 * * \\
(0.1088)\end{array}$ & $\begin{array}{r}-0.0504 \\
(0.1517)\end{array}$ & $\begin{array}{r}-0.5693 \\
(0.4582)\end{array}$ \\
\hline Change in Fraction of Filers & $\begin{array}{c}0.2088 \\
(0.1821)\end{array}$ & & $\begin{array}{c}0.2546 \\
(0.1607)\end{array}$ \\
\hline $\begin{array}{l}\text { Controls for changes in other } \\
\text { personal tax rates and in top } \\
\text { income shares? }\end{array}$ & $\mathrm{Y}$ & $\mathrm{Y}$ & Y \\
\hline Sample Period & $1929-2000$ & $1946-2000$ & 1929-1975 \\
\hline No. of Obs. & 63 & 47 & 38 \\
\hline $\begin{array}{l}\text { F-Statistic (p-value in } \\
\text { parantheses) }\end{array}$ & $\begin{array}{l}2.90 \text { *** } \\
(0.0027)\end{array}$ & $\begin{array}{l}4.57 \text { *** } \\
(0.0002)\end{array}$ & $\begin{array}{l}4.65 \text { *** } \\
(0.0006)\end{array}$ \\
\hline
\end{tabular}

\section{Change in Stock Ownership Concentration Index}

(2)

0.0016
$(0.0058)$

$-0.2103 * *$

(0.0027)

$-0.0194$

0.2054

$(0.4582)$

0.2546

$(0.1607)$

1929-1975

38

(0.0006) the $10 \%, 5 \%$ and $1 \%$ levels, respectively. 
Table 4

Taxes and Stock Ownership Concentration: Maximum-Likelihood AR(1) Results

Dependent Variable:

\begin{tabular}{|c|c|c|c|}
\hline & $(1)$ & (2) & (3) \\
\hline Constant & $\begin{array}{r}-0.0006 \\
(0.0028)\end{array}$ & $\begin{array}{r}-0.0061 \\
(0.0056)\end{array}$ & $\begin{array}{r}0.0006 \\
(0.0033)\end{array}$ \\
\hline $\begin{array}{l}\text { Change in Top Statutory } \\
\text { Personal Tax Rate }\end{array}$ & $\begin{array}{l}-0.1385 * * \\
(0.0614)\end{array}$ & $\begin{array}{l}-0.6206 * * \\
(0.2905)\end{array}$ & $\begin{array}{l}-0.1793 \text { *** } \\
(0.0626)\end{array}$ \\
\hline Change in real GDP per capita & $\begin{array}{r}-0.0091 \\
(0.0069)\end{array}$ & $\begin{array}{r}0.0027 \\
(0.0065)\end{array}$ & $\begin{array}{l}-0.0119 * \\
(0.0062)\end{array}$ \\
\hline Change in Price-Earnings Ratio & $\begin{array}{l}-0.0017 * * \\
(0.0008)\end{array}$ & $\begin{array}{l}-0.0024^{* * *} \\
(0.0008)\end{array}$ & $\begin{array}{r}-0.0022 \\
(0.0014)\end{array}$ \\
\hline Change in Dividend Yield & $\begin{array}{l}-0.0104 * \\
(0.0062)\end{array}$ & $\begin{array}{r}-0.0062 \\
(0.0055)\end{array}$ & $\begin{array}{l}-0.0160 * \\
0.0082\end{array}$ \\
\hline Change in Corporate Tax Rate & $\begin{array}{r}-0.1116 \\
(0.2061)\end{array}$ & $\begin{array}{c}0.4984 \\
(0.3033)\end{array}$ & $\begin{array}{c}0.0898 \\
(0.1696)\end{array}$ \\
\hline $\begin{array}{l}\text { Change in Capital Gains Tax } \\
\text { Rate }\end{array}$ & $\begin{array}{c}0.2157 \\
(0.2546)\end{array}$ & $\begin{array}{r}0.0069 \\
(0.2465)\end{array}$ & $\begin{array}{l}0.6536 * * \\
(0.3252)\end{array}$ \\
\hline $\begin{array}{l}\text { Change in Effective Capital } \\
\text { Gains Tax Rate }\end{array}$ & $\begin{array}{r}-0.1146 \\
(0.1039)\end{array}$ & $\begin{array}{r}-0.1929 \\
(0.1577)\end{array}$ & $\begin{array}{r}-0.2386 \\
(0.2388)\end{array}$ \\
\hline Change in Fraction of Filers & $\begin{array}{l}0.28966^{* *} \\
(0.1292)\end{array}$ & & $\begin{array}{l}0.39599^{* * *} \\
(0.0900)\end{array}$ \\
\hline $\begin{array}{l}\rho \text { (First-order autocorrelation } \\
\text { parameter) }\end{array}$ & $\begin{array}{l}-0.4270 * * \\
(0.2054)\end{array}$ & $\begin{array}{l}0.5330 * * * \\
(0.2024)\end{array}$ & $\begin{array}{l}-0.65177^{* * *} \\
(0.1643)\end{array}$ \\
\hline $\begin{array}{l}\text { Controls for changes in other } \\
\text { personal tax rates and in top } \\
\text { income shares? }\end{array}$ & $\mathrm{Y}$ & $\mathrm{Y}$ & $\mathrm{Y}$ \\
\hline Sample Period & $1929-2000$ & $1946-2000$ & $1929-1975$ \\
\hline No. of Obs. & 63 & 47 & 38 \\
\hline $\begin{array}{l}\text { Wald Statistic (p-values in } \\
\text { paratheses) }\end{array}$ & $\begin{array}{l}63.91 \text { *** } \\
(0.0000)\end{array}$ & $\begin{array}{l}304.28 \text { *** } \\
(0.0000)\end{array}$ & $\begin{array}{l}258.27^{* * *} \\
(0.0000)\end{array}$ \\
\hline
\end{tabular}

Change in Stock Ownership Concentration Index 
Table 5

Taxes and Stock Ownership by Income Quintiles (OLS Results with Newey-West Standard Errors)

\begin{tabular}{|c|c|c|c|c|c|}
\hline & (1) & (2) & (3) & (4) & (5) \\
\hline Dependent Variable: & $\begin{array}{c}\text { Share of } \\
\text { Corporate } \\
\text { Equity held } \\
\text { by Top } \\
\text { Quintile }\end{array}$ & $\begin{array}{c}\text { Share of } \\
\text { Corporate } \\
\text { Equity held } \\
\text { by 2nd } \\
\text { Quintile }\end{array}$ & $\begin{array}{c}\text { Share of } \\
\text { Corporate } \\
\text { Equity held } \\
\text { by 3rd } \\
\text { Quintile } \\
\end{array}$ & $\begin{array}{c}\text { Share of } \\
\text { Corporate } \\
\text { Equity held } \\
\text { by 4th } \\
\text { Quintile } \\
\end{array}$ & $\begin{array}{c}\text { Share of } \\
\text { Corporate } \\
\text { Equity held } \\
\text { by Lowest } \\
\text { Quintile }\end{array}$ \\
\hline Constant & $\begin{array}{r}-0.0598 \\
(0.2899)\end{array}$ & $\begin{array}{r}0.0151 \\
(0.1536)\end{array}$ & $\begin{array}{l}-0.0061 \\
(0.0907)\end{array}$ & $\begin{array}{r}0.0403 \\
(0.1249)\end{array}$ & $\begin{array}{r}0.0014 \\
(0.0752)\end{array}$ \\
\hline $\begin{array}{l}\text { Top Statutory Personal Tax } \\
\text { Rate }\end{array}$ & $\begin{array}{l}-10.4581 * * \\
(4.9523)\end{array}$ & $\begin{array}{l}6.3099 * * \\
(2.8656)\end{array}$ & $\begin{array}{l}4.5086 * * * \\
(1.2802)\end{array}$ & $\begin{array}{r}2.3652 \\
(1.6426)\end{array}$ & $\begin{array}{r}0.2615 \\
(2.8190)\end{array}$ \\
\hline $\begin{array}{l}\text { Change in real GDP per } \\
\text { capita }\end{array}$ & $\begin{array}{r}-0.4264 \\
(0.6072)\end{array}$ & $\begin{array}{r}0.1136 \\
(0.2947)\end{array}$ & $\begin{array}{r}0.1800 \\
(0.1928)\end{array}$ & $\begin{array}{r}-0.0094 \\
(0.2214)\end{array}$ & $\begin{array}{r}0.0714 \\
(0.1437)\end{array}$ \\
\hline $\begin{array}{l}\text { Change in Price-Earnings } \\
\text { Ratio }\end{array}$ & $\begin{array}{l}-0.1330 \\
(0.0859)\end{array}$ & $\begin{array}{r}0.0702 \\
(0.0440)\end{array}$ & $\begin{array}{r}0.0215 \\
(0.0344)\end{array}$ & $\begin{array}{r}0.0322 \\
(0.0280)\end{array}$ & $\begin{array}{l}-0.0185 \\
(0.0376)\end{array}$ \\
\hline $\begin{array}{l}\text { Lagged Change in Price- } \\
\text { Earnings Ratio }\end{array}$ & $\begin{array}{l}-0.0412 \\
(0.0673)\end{array}$ & $\begin{array}{r}0.0186 \\
(0.0400)\end{array}$ & $\begin{array}{l}-0.0007 \\
(0.0231)\end{array}$ & $\begin{array}{c}0.0427 \\
(0.0289)\end{array}$ & $\begin{array}{l}-0.0130 \\
(0.0197)\end{array}$ \\
\hline Change in Dividend Yield & $\begin{array}{l}-0.9022 \\
(0.5447)\end{array}$ & $\begin{array}{r}0.0872 \\
(0.2771)\end{array}$ & $\begin{array}{r}0.1582 \\
(0.1585)\end{array}$ & $\begin{array}{r}0.2679 \\
(0.2031)\end{array}$ & $\begin{array}{r}0.1890 \\
(0.1875)\end{array}$ \\
\hline $\begin{array}{l}\text { Change in Corporate Tax } \\
\text { Rate }\end{array}$ & $\begin{array}{r}0.8510 \\
(17.3182)\end{array}$ & $\begin{array}{r}2.0745 \\
(9.0101)\end{array}$ & $\begin{array}{l}-4.6501 \\
(5.2537)\end{array}$ & $\begin{array}{r}-7.9491 \\
(7.0603)\end{array}$ & $\begin{array}{l}10.4458 \\
(8.8345)\end{array}$ \\
\hline $\begin{array}{l}\text { Change in Capital Gains } \\
\text { Tax Rate }\end{array}$ & $\begin{array}{r}25.8286 \\
(21.6814)\end{array}$ & $\begin{array}{l}-0.2680 \\
(9.2005)\end{array}$ & $\begin{array}{l}-14.9347 * * \\
(6.9027)\end{array}$ & $\begin{array}{l}-6.8450 \\
(5.5332)\end{array}$ & $\begin{array}{r}-7.2466 \\
(9.8933)\end{array}$ \\
\hline $\begin{array}{l}\text { Change in Effective Capital } \\
\text { Gains Tax Rate }\end{array}$ & $\begin{array}{l}-13.8747 * \\
(7.9450)\end{array}$ & $\begin{array}{c}0.2997 \\
(4.0679)\end{array}$ & $\begin{array}{c}7.8035 \\
(5.3334)\end{array}$ & $\begin{array}{l}5.5314 * * \\
(2.4007)\end{array}$ & $\begin{array}{c}1.8581 \\
(3.8999)\end{array}$ \\
\hline Change in Fraction of Filers & $\begin{array}{r}13.5533 \\
(12.0902)\end{array}$ & $\begin{array}{l}-4.5488 \\
(6.3079)\end{array}$ & $\begin{array}{r}-1.9463 \\
(2.4370)\end{array}$ & $\begin{array}{r}-0.6531 \\
(4.4515)\end{array}$ & $\begin{array}{l}-4.2661 \\
(3.7229)\end{array}$ \\
\hline $\begin{array}{l}\text { Controls for changes in } \\
\text { other personal tax rates and } \\
\text { in top income shares? }\end{array}$ & $\mathrm{Y}$ & $\mathrm{Y}$ & $\mathrm{Y}$ & $\mathrm{Y}$ & $\mathrm{Y}$ \\
\hline Sample Period & $1929-2000$ & $1929-2000$ & $1929-2000$ & $1929-2000$ & $1929-2000$ \\
\hline No. of Obs. & 63 & 63 & 63 & 63 & 63 \\
\hline $\begin{array}{l}\text { F-Statistic (p-value in } \\
\text { parantheses) }\end{array}$ & $\begin{array}{l}2.79 * * * \\
(0.0033)\end{array}$ & $\begin{array}{l}2.15^{* *} \\
(0.0217)\end{array}$ & $\begin{array}{l}4.96 \text { *** } \\
(0.0000)\end{array}$ & $\begin{array}{l}2.70 * * * \\
(0.0044)\end{array}$ & $\begin{array}{r}1.38 \\
(0.1925)\end{array}$ \\
\hline
\end{tabular}

Note: Newey-West standard errors, using 1 lag in the autocorrelation structure, are reported in parantheses; ${ }^{*}, * *$ and ${ }^{* * *}$ denote significance at the $10 \%, 5 \%$ and $1 \%$ levels, respectively. 